\title{
INTERFACES HÍBRIDAS: ARMAS E ARMADILHAS DE CAÇA E PESCA NO ALTO RIO NEGRO
}

\author{
Thiago Lopes da Costa Oliveira ${ }^{1}$
}

\section{Introdução}

Neste texto, trato das técnicas de caça e pesca empregadas pelos Baniwa e outros povos da região do alto rio Negro. Inicialmente, descreverei o ambiente técnico desta região - sua conformação ecológica. Em seguida, apresentarei algumas das técnicas empregadas nas atividades acima referidas. Diante do exposto, e dada a proliferação de agentes humanos e não-humanos nestas técnicas, questionarei, progressivamente, uma abordagem antropocentrada da atividade cinegética e da pesca realizadas pelos índios do alto rio Negro. ${ }^{2}$

\section{O ambiente técnico do alto rio Negro}

O alto rio Negro é um sistema multiétnico, onde vivem 23 povos, com uma das maiores populações indígenas do Brasil. Somente os Baniwa, junto aos quais realizo pesquisas desde 2011, são cerca de 6000 indivíduos em nosso território. Este sistema multiétnico é coeso de inúmeros pontos de vista: organização social, ritual, econômica, ecológica, tecnológica e da cultura material. ${ }^{3}$

\footnotetext{
${ }^{1}$ Universidade Federal do Rio de Janeiro e Museu do Índio - FUNAI - UNESCO, Brasil.

${ }^{2}$ Agradeço aos participantes do "GT - 09 Antropologia das relações humano-animal" da $30^{\mathrm{a}}$ Reunião Brasileira de Antropologia pelos comentários e perguntas colocados para uma versão preliminar deste texto. Agradeço especialmente aos pareceristas anônimos pelas sugestões e críticas e aos Baniwa, que me acompanharam nestas pesquisas e compartilharam comigo seu conhecimento. Os erros persistentes no trabalho são, evidentemente, de minha inteira responsabilidade.

${ }^{3}$ As noções de "nexo regional" (Cabalzar, 2000) e de "comunidade ritual" (Lolli, 2010) permitem tratar dos principais características sociais, rituais, econômicas e sociais dos grupos da região como parte de um "sistema de transformação" (ver Hugh-Jones, 2002, dentre outros, sobre esta noção).
} 


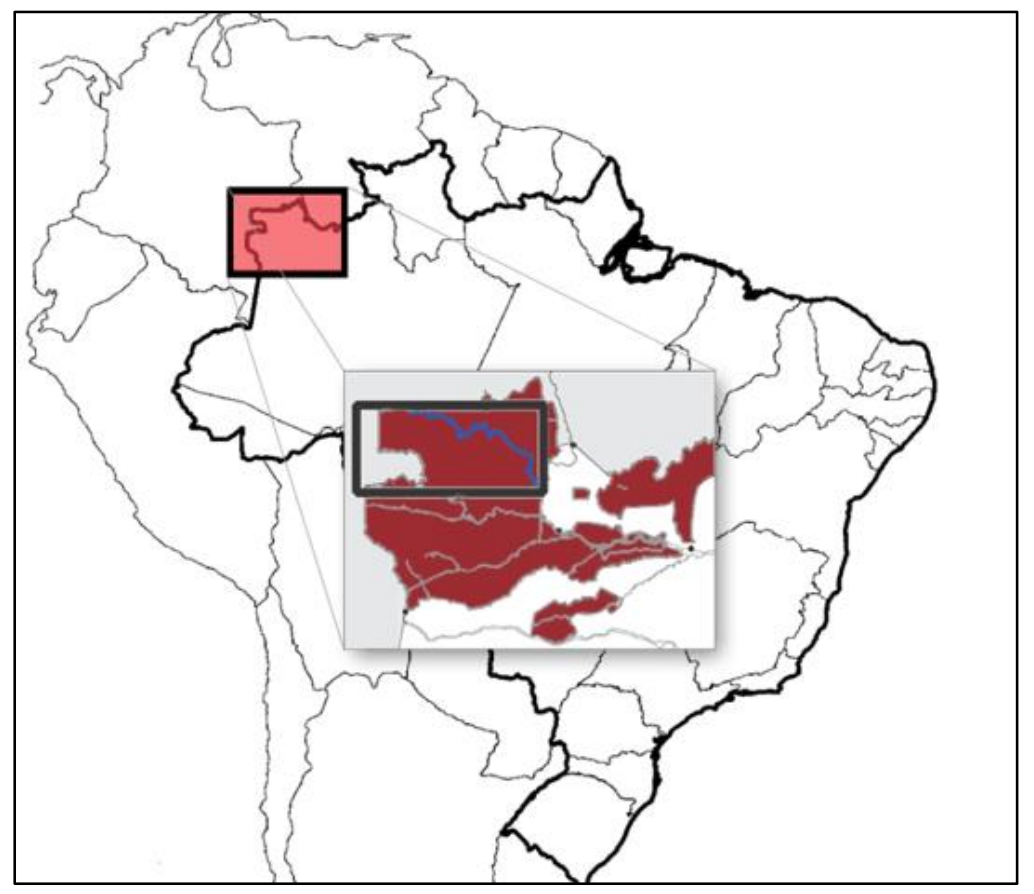

Figura 1: Mapa Brasil, destaque região alto rio Negro - fonte PIB - ISA.

A cultura material foi a minha área de concentração, em especial, junto aos Baniwa do clã Hohodeni, que vivem na região de Ucuqui-Cachoeira, no igarapé Uaranã, um dos formadores do rio Aiari. ${ }^{4}$ É a partir da cultura material da região que vou tratar da caça e da pesca neste texto.

Para situar o conhecimento Hohodeni em relação ao conhecimento de outros povos da região é preciso dizer que eles vivem em uma região de "cabeceiras", de formadores de rio. A conformação ecológica deste tipo de região, embora se encaixe no perfil mais amplo da paisagem rionegrina, apresenta, ao mesmo tempo, particularidades importantes a serem consideradas na descrição do ambiente técnico em que se executam as atividades de caça e pesca.

Começo pelas semelhanças. No alto Aiari, como no restante da bacia do rio Negro a alta acidez do solo limita a proliferação da vida como um todo. Esta é uma região marcada pelo baixo rendimento da caça, da pesca e da agricultura, onde espécies vegetais, animais e minerais ocorrem de forma exclusiva e concentrada em determinadas nichos do território. Em função destas limitações - dentre as quais as limitações de solos agriculturáveis são as mais importantes -, os grupos humanos se dispersam em pequenos núcleos que, em sua maioria, tem entre 30 e 50 pessoas.

\footnotetext{
${ }^{4} \mathrm{O}$ rio Aiari é formador do Içana, que, por sua vez, é formador do rio Negro.
} 
Acredita-se que a especialização artesanal característica da região, por exemplo, seja uma função desta dispersão territorial e da limitação local de acesso aos recursos (sobre este tema ver Galvão 1959; Ribeiro 1980, 1995; Cabalzar e Ricardo 2006, Oliveira, 2015). A troca seria uma forma dos grupos locais explorarem conjuntamente um território relativamente inóspito, aproveitando o melhor que pode oferecer cada microregião.

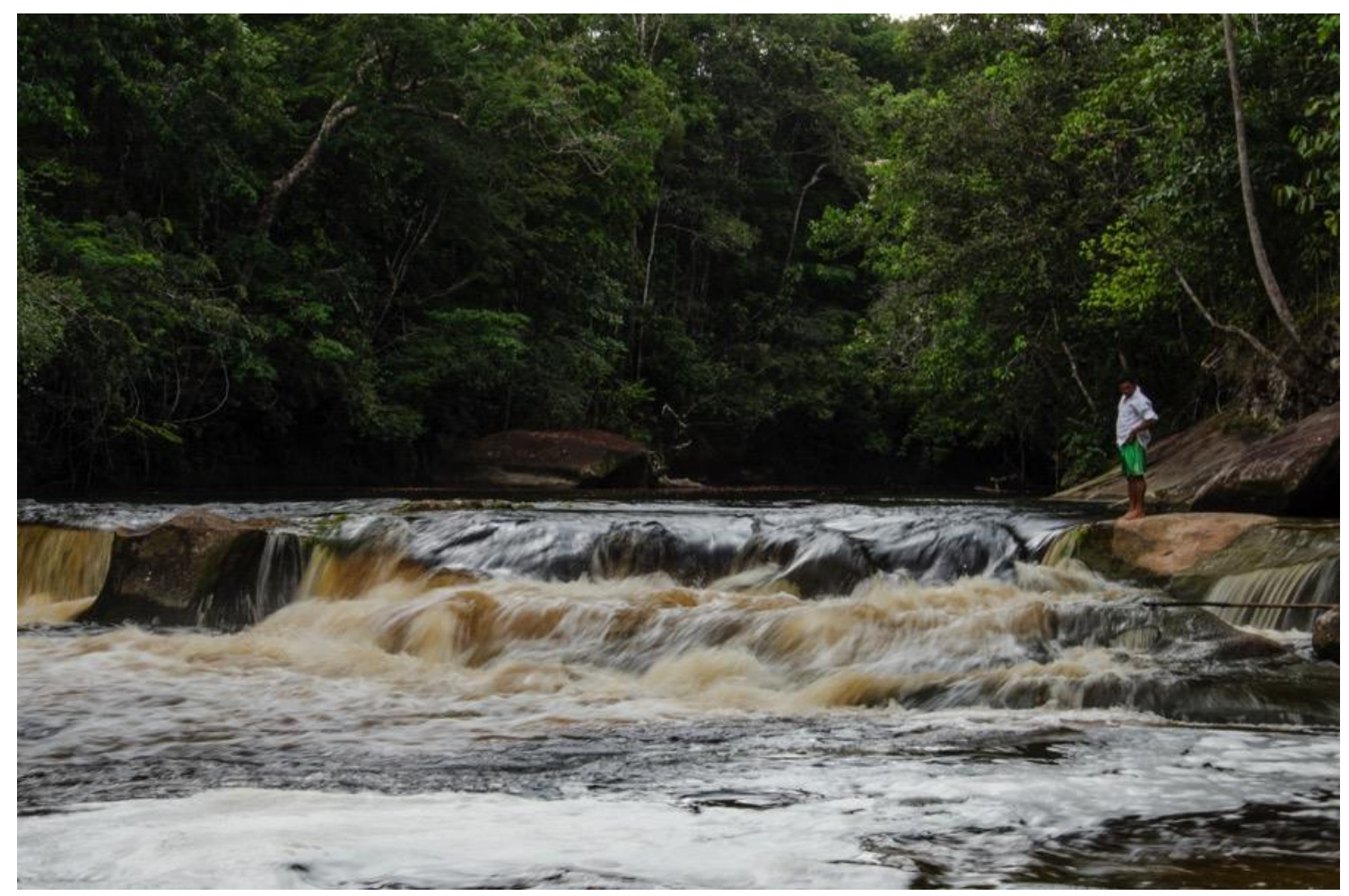

Figura 2: Corredeira no igarapé Uaranã. Existem dezenas de pequenas e grandes corredeiras como estas ao longo dos cursos do rios da região - foto do autor.

No que diz respeito às diferenças ecológicas, o fato de a região do alto Aiari ser uma área de cabeceiras torna este ambiente, em alguns sentidos, ainda mais inóspito. Peixes de grande porte, presentes nos trechos mais baixos do rio Negro e de seus formadores, por exemplo, não ocorrem por lá. Assim como não ocorrem botos, arraias e as maiores espécies de jacarés - isso se deve ao grande número de cachoeiras e corredeiras presentes na região (ver figura 2). Tal limitação hidrológica faz com que a obtenção de proteína animal de origem aquática seja menor, em comparação às partes mais baixas do rio Negro. 
Os recursos de caça, em toda região, alteram-se em função da disponibilidade de terra firme - áreas em que ocorrem mamíferos de médio porte, como antas e porcos do mato. Estas áreas são raras em todo alto rio Negro. No alto Aiari, há grande disponibilidade de terra firme e, portanto, um grande estoque de caça. Nas áreas de caatinga a disponibilidade de mamíferos diminui, mas aumenta a de aves.

Este tipo de peculiaridade ecológica faz da caça e da pesca atividades altamente técnicas e valorizadas. Ser um bom caçador/pescador, um "marupiara", ou ser um mau caçador/pescador, um "panema", faz diferença no dia a dia. ${ }^{5}$

As técnicas de caça e pesca são ensinadas desde a infância. Os jovens do sexo masculino acompanham seus pais, tios e avôs desde cerca de 7 anos de idade, em contextos progressivamente mais arriscados. As crianças também aprendem entre si, caçando e pescando a curtas distancias da aldeia. Entre os povos da região, crianças de ambos os sexos são responsáveis, muito cedo, por parte de sua alimentação. Há, além disso, um momento de aprendizado mais dedicado, que compreende a iniciação dos jovens do sexo masculino. Nesta ocasião, confinados em acampamentos nas florestas, os jovens recebem noções técnicas mais aprofundadas sobre o território em que nasceram, tendo acesso a conhecimentos específicos a respeito de plantas, animais e nichos territoriais da área em que vivem.

Este conhecimento transmitido de geração a geração pode ser complementado com recursos mágico-rituais. A constituição do corpo de um bom caçador e pescador pode começar cedo, com aplicação de monotsi no seu umbigo, ainda enquanto recémnascido. Monotsi é o equivalente em baniwa para o termo "puçanga", em língua geral. Trata-se de substâncias geralmente de origem vegetal, adquiridas algumas vezes por um alto valor, que tem o poder de tornar o seu receptor "atraente" para as presas que caça.

As metáforas de sedução são importantes referenciais no discurso sobre a caça e pesca (ver Corredor, 2011: 105). Quando se referem à alguém que "tem puçanga”, os Baniwa dizem que tal pessoa exerce atração sobre os animais. Conheci um ótimo pescador e caçador que dizia que, dada a sua eficácia na caça e na pesca, teria recebido puçanga quando era bebê. Em função da interação com a substância, ele teve que cumprir restrições alimentares durante toda a sua primeira infância (até cerca de 7

\footnotetext{
${ }^{5}$ Termos em destaque vem da língua geral, o tupi pan-amazônico introduzido na região pelos Carmelitas, ainda no século XVII.
} 
anos), não comendo determinados animais e/ou partes de animais. ${ }^{6}$ Embora seu sucesso possa ser atribuído ao tratamento que recebeu na infância, tratava-se, evidentemente, de um indivíduo com densa capacidade de leitura do ecossistema regional, tendo aprendido, desde jovem, a ver na paisagem as marcas, os desejos e os movimentos das presas a abater. Voltarei a isso mais adiante.

Aqueles que não dispõem de conhecimento especializado e não foram tratados com monotsi na infância, recorrem, hoje em dia, a algumas tecnologias alienígenas, como a pesca de arrastão com redes - as chamadas malhadeiras -, ou o mergulho com as máscaras - as chamadas "careta" - munidos de arpão. Estas técnicas, embora sejam eficazes num primeiro momento, não o são, em geral, em um longo prazo. Elas acabam “espantando os peixes" que deixam de passar ou dormir em determinadas partes do rio.

O mesmo pode ser dito do uso de armas de fogo. Esta é uma das regiões em que, no passado, se fazia largo uso de zarabatanas com flechas de pontas embebidas em curare para caça de animais arborícolas. O curare é um veneno de origem vegetal feito a partir de um conjunto de plantas. Ele atua nas presas paralisando a sua musculatura. Em um intervalo de segundos ou minutos - a depender do tamanho do animal e da potencia do veneno - a morte da presa ocorre pela interrupção dos batimentos cardíacos. As flechas de zarabatana são um algoz silencioso, capaz de abater mais de meia dúzia de macacos sem que o bando se dê conta exatamente do que está ocorrendo. O mesmo não se passa com a ruidosa espingarda, que provoca a fuga desesperada dos animais ao ressoar da primeira explosão de pólvora. Animais terrestres e arborícolas, de tanto escutar tiros, também "ficam ariscos, fogem e vão morar longe", como diziam os meus interlocutores.

Percebe-se então que os objetos e técnicas usados na caça e na pesca se relacionam com o comportamento dos animais, e que os animais reagem aos meios empregados no seu abate. Este são os pontos que gostaria de explorar nas próximas seções.

\footnotetext{
${ }^{6}$ As restrições alimentares estão fortemente associadas ao monotsi e a outros procedimentos rituais. Ver Buchillet (1988, 1997); Hugh-Jones (1996) e Oliveira (2015) sobre a relação entre os atos rituais chamados regionalmente de benzimentos e a dieta na região.
} 


\section{Técnicas de caça e pesca}

As técnicas de caça e pesca empregadas tradicionalmente na região - a caça com arcos, flechas e zarabatanas; a pesca com anzóis e armadilhas - são, no geral, consideradas não intrusivas. Ou seja, elas não modificariam, segundo os índios, o comportamento dos animais. Tais técnicas, ao contrário, encontram-se em sintonia com o comportamento das presas, interagindo com o conhecimento dos hábitos de cada espécie visada, para a consecução dos objetivos humanos. Por isso, as considerarei como objeto deste trabalho.

George Frison - um caçador experiente que, aos 37 anos, iniciou sua formação em arqueologia, voltada para o estudo da caça e da etologia pré-históricas -, analisando técnicas contemporâneas e registros arqueológicos da caça de mamíferos de médio porte nas planícies do Oeste e Noroeste da América do Norte, destacou um conjunto de variáveis que devem ser levadas em conta para a compreensão das técnicas de caça de um modo geral. Segundo o autor (2004), as estratégias dos caçadores para encontrar um animal onde as experiências passadas dizem que ele deve estar consideram: o clima (a época do ano, a hora do dia), o território (a vegetação e a topografia), o estado possível do animal, a localização de fontes de água (: 153,223,229), dentre outros fatores. Tais estratégias estão também sujeitas aos imprevistos característicos deste tipo de atividade - o alerta de um pássaro, ou um galho que se quebra e espanta o animal visado; a presença de um predador concorrente, uma mudança de vento (: 223), etc. Ao mesmo tempo, estas estratégias mudam de acordo com o sexo, a idade, o tamanho e a condição corporal do caçador (: 229).

As definições de Frison apontam que a caça depende, fundamentalmente, de duas coisas: de um lado, da leitura do ambiente terrestre e das suas transformações sazonais, de outro, do conhecimento do comportamento de cada animal e da sua relação com o ambiente em que vive - o restante seria contingência. Abordarei, em seguida, tanto a leitura territorial característica da caça e da pesca no alto rio Negro, quanto a relação entre esta leitura e o comportamento de animais terrestres e aquáticos na região. 


\section{A caça}

\subsection{Plantas como índices}

Em suas caminhadas pelas matas e trilhas que os cercam, os Baniwa observam as plantas que estão florescendo ou frutificando, e sabem, em função disso, quais pássaros e mamíferos terrestres e arborícolas se movimentam em resposta a estes processos. Visando compreender o modo como esta população interage com o território em que vive, realizei, em 2012, um levantamento de cerca de $5 \mathrm{~km}$ de trilhas florestais, recenseando as plantas encontradas às margens destas trilhas e descrevendo seu uso. Neste processo, encontramos, os Baniwa e eu, 241 espécies vegetais das quais apenas 49 não tinham uso identificado. ${ }^{7} \mathrm{O}$ restante é empregado como alimento (36), remédio (62) ou para se fazer artefatos, construções, pescar e caçar animais (121); existindo, em alguns casos, a ocorrência simultânea dos três usos. Os dados a seguir tem origem neste levantamento. ${ }^{8}$

Uma planta, domatsi panali, por exemplo, é conhecida como "a roça dos jacus" (Penelope sp.) e tucanos (Ramphastos tucanus e outros), uma vez que estes animais se servem frequentemente de seus frutos. Hemali Panali, ixedoni eedzawetta e maapidzada alimentam, por sua vez, macacos de diversas espécies, como o macaco barrigudo (Lagothrix lagotricha), o guariba (Alouatta), o prego (Cebus apella), o zogzog (Callicebus dubius) e o macaco da noite (Aotus sp.). O palmito de makoatsi, uma espécie espinhosa de palmeira, é especialmente apreciado pelos macacos-prego. Quando avistam esta planta, aqueles que tem estes animais como xerimbabos retiram uma porção do palmito para levar ao seu animal de estimação. Heema, as antas (Tapirus terrestris), dão nome à algumas das árvores que fornecem seus alimentos preferidos, como heema dokoole e heema doomáli. Alguns destes alimentos, como os frutos do iittewi, também são comidos por dzaapa, pacas (Cuniculus paca). Esta, por sua vez também dá nome a uma planta de que se alimenta dzaapa ikakolaphina.

\footnotetext{
${ }^{7}$ Trabalho de campo realizado durante pesquisa de doutorado e apoiado pelo Projeto de Documentação das Culturas e Línguas Indígenas do Museu do Índio - FUNAI - UNESCO e por editais da CAPES, CNPq e FAPERJ.

${ }^{8}$ Não foi possível, na maioria das vezes, identificar as espécies vegetais mencionadas. Tal identificação ainda será feita em etapas posteriores da pesquisa. Neste texto, como convenção, quando houver identificação da planta ou animal, a apresentarei em seguida ao nome em baniwa, entre parenteses. Quando não houver, apresentarei somente o nome baniwa, evitando assim escrever inúmeras vezes "espécie não identificada".
} 
Quando veem frutos comidos, os caçadores procuram por rastros dos animais a eles relacionados. Seguem, assim, na trilha de suas vítimas com os olhos atentos ao menor movimento, procurando fazer o menor ruído possível. Estes vegetais de que os animais se alimentam são, portanto, índices de sua presença. Eles ajudam a orientar os índios no território de caça. Estes índices se somam aos outros à outras referências que guiam os Baniwa pelas matas: um caçador sempre sabe onde está situado em referência à rede de trilhas e igarapés da região e também em relação aos biomas que atravessa. Estes últimos são conhecidos a partir de um esquema classificatório que contém unidades progressivamente inclusivas - indo dos grandes biomas, como eedzawa, terra firme; heñame, capoeiras; hamaliana, campinarana e alape, igapó; até os micro-biomas, matas em que predominam cerca de 5 a 10 espécies que se alternam em intervalos irregulares, recobrindo desde alguns poucos até algumas dezenas de metros. ${ }^{9}$

O reconhecimento dos vegetais que apontam para a presença dos animais é apenas o início do processo da caça. Ao ter certeza de ter encontrado um rastro, sem conseguir avistar o animal, o caçador pode lançar mão de diferentes técnicas, tais como a construção de um jirau de espera - técnica empregada para mamíferos relativamente grandes, como antas -, a abertura de um buraco que será posteriormente coberto e sobre o qual serão dispostas iscas - o "mundéu" - e mesmo a instalação de armadilhas que, ativadas pela passagem do animal, erguem-no pelas patas (ver Brüzzi Alves da Silva, 1994[1977]: 217-8 sobre estas armadilhas).

Muitas vezes os índios são acompanhados de cães de caça. Estes seguem um comportamento característico ao percorrer as trilhas: varrem-nas em zig-zag, passando de tempos em tempos pelo caçador que segue na pequena clareira que atravessa a vegetação. Caçador e cachorro se comunicam de longe, por meio de gritos e assobios da parte do primeiro e de latidos da parte do segundo. A insistência do cachorro em latir em uma determinada região faz o caçador abandonar a trilha e enfrentar a vegetação cerrada, em busca da presa.

As trilhas de floresta são o resultado de um trabalho contínuo e geracional. Ligam, por terra, pontos distantes de ocupação humana também alcançáveis por rio. Ir de um ponto a outro por via terrestre é o que permite a caça. Algumas destas trilhas se

\footnotetext{
${ }^{9} \mathrm{O}$ valor indicial das plantas é fundamental para a interação dos índios da região com ambiente que os cerca. Tal valor é importante não só para encontrar animais, mas também outras plantas, ou ainda identificar os terrenos adequados para o cultivo de mandioca e pimenta. A árvore Kadáapo, por exemplo, é um índice dos primeiros, enquanto a árvore Mokooli indica a presença dos seguintes. Sobre o tema ver Oliveira (2015, cap. 4).
} 
fecham, por falta de uso - em função da desocupação da área de destino ou da diminuição da disponibilidade de animais na região. Estes caminhos podem ser depois recuperados, pois as marcas impressas no território pelo contínuo uso humano levam, por vezes, muitos anos para serem apagadas.

\section{Plantas como possibilidades partilhadas}

Outra categoria de plantas indiciais são aquelas partilhadas por humanos e nãohumanos. Dzookoroda e maaliwanahi, por exemplo, dão frutos que alimentam humanos e macacos - o segundo sendo também empregado na elaboração de hastes de flechas. Heema dzekani é alimento das antas e tem a sua casca empregada nas paredes das casas construídas pelos humanos. Já madeeri koodana tem o fruto por vezes comido por antas e veados - sendo que estes últimos também comem as suas flores - e a casca utilizada na elaboração de pequenas embalagens. Dzaawaka, além de oferecer uma boa lenha para humanos, tem a fruta comida por macacos-prego, barrigudos e monochocoto ${ }^{10}$. Manakhe, o açaí selvagem (Euterpe oleracea), do qual os humanos aproveitam as frutas fazendo "vinho", é isca para aracu (Leporinus klausewitz e Leporinus agassizi), além de ser alimento para tucanos e japus (Oropendolas sp.). Outro vegetal partilhado por humanos, peixes e pássaros é o mapoorotti. O seu fruto serve para pescar aracu e pacu (Piaractus brachypomus), alimentando também macacos e o pássaro towiri, os japus, um animal de cujas penas se faz adornos de cabeça. Os humanos não comem destes frutos, mas usam a lenha desta árvore para aquecer seus alambiques. Outra lenha ainda apreciada pelos humanos é a de tewirida, empregada especialmente para fazer tapioca. Jacus e tucanos comem dos frutos destas plantas, além de outros pássaros.

O que se percebe destes usos partilhados é que a consecução das atividades cotidianas pode levar a uma caçada inesperada ou não planejada. Pode ocorrer de um indivíduo sair para pegar lenha para seu alambique e se deparar com macacos na copa da árvore mapoorotti, alimentando-se dos seus frutos. Ou que outro sujeito tenha o apetite aberto ao ver os frutos do açaí selvagem, e volte para casa com alguns tucanos para o jantar ou para fazer adornos. Pode ser, ainda, que a procura de envira, um indivíduo se depare com um belo veado vermelho - banquete dos banquetes - comendo

\footnotetext{
${ }^{10}$ Termo em espanhol para o qual não consegui equivalente em português.
} 
as flores de madeeri koodana; ou de, nas imediações desta árvore, um rastro recente levar o caçador até uma anta. ${ }^{11}$

Por estes exemplos, percebe-se que o território por onde passam os índios na consecução de suas atividades cotidianas é algo vivo, marcado por aquilo que o psicólogo ecológico-cognitivo James Gibson (2014[1979]) chamou de affordances possibilidades inscritas na superfície das coisas que permitem que nos sirvamos delas de um modo específico. As affordances são "valores ecológicos" que permitem fazer algo, obter certos recursos, ou escapar de perigos e armadilhas (Reed, 1988: 112). Assim, diante das múltiplas possibilidades colocadas pelo meio - pelas plantas ali presentes, úteis tanto a humanos quanto a animais não-humanos - não podemos deixar de atribuir a estes vegetais, uma parte da agência do ato cinegético. Uma agência que, frequentemente, depositamos exclusivamente nas ações e intenções dos humanos. ${ }^{12}$

As próprias armas tradicionais empregadas na caça e na pesca são o resultado de affordances, possibilidades desenvolvidas pelos humanos a partir de características presentes no vegetais. As zarabatanas [figura 3] dos Baniwa, por exemplo, tem a "alma" - a parte por onde passam os projéteis - feitas de uma planta chamada mawixapi. Esta planta, encontrada somente em raríssimas áreas da bacia do rio Içana, possui cânulas cujo interior é oco e tem o diâmetro regular por cerca de 4 metros. Tal característica faz de mawixapi o material ideal para a passagem precisa dos dardos kaapitsiriíta envenenados. ${ }^{13}$ Estes, por sua vez, são feitos a partir de um longo espinho que se encontra aos montes na base da palmeira patauá. Tais espinhos tem características espessura e resistência - que permitem a máxima precisão do arremesso. Para atravessar o tubo, os dardos dependem da colocação precisa de paina de pirimitsi, samaúma (Ceiba pentandra). Esta colocação depende, por sua vez, do uso de um cordel, o heeriwai, feito de curauá (Ananas sativa) e breu. A parte de baixo das setas devem se encaixar

\footnotetext{
${ }^{11}$ Algumas plantas partilhadas entre espécies diferentes servem como remédio para os humanos, este é o caso da árvore towinapi, preferida pelos japus, towiri, para fazer seus ninhos. A lenha de towinapi é usada pelos Baniwa em benzimentos para se proteger de seres da floresta que os atacam, os chamados yoopinai - voltarei a falar deles abaixo. Já poixeni, cujos frutos são comidos por tucanos e jacus, é empregada também como remédio para olhos humanos.

${ }^{12}$ Em um artigo interessante, "The materiality of plants: plant-people entanglements", Marijke van der Veen (2014) apresenta uma visão do relacionamento entre humanos e plantas de uma perspectiva não antropocêntrica, recuperando a agência das plantas nos processos em que elas aparecem como simples pacientes. Para a autora, plantas são parte ativa dos processos de domesticação, cultivo, desmatamento, alimentação, etc..

${ }^{13}$ Segundo Koch-Grünberg (2005) as zarabatanas maku possuiam outro tipo de construção, sendo feitas apenas de duas peças de jupati trabalhadas e acopladas. (: 121ss). Notícias mais recentes destes índios do subgrupo Nukak - indicam que tais artefatos sejam alvo de uma elaboração semelhante à dos Baniwa (ver Politis 2007: 170)
} 
perfeitamente ao tubo interno da zarabatana para que o sopro possa exercer pressão sobre o conjunto.

O veneno mawakooli é colocado na afiadíssima parte frontal da seta e, para evitar acidentes, as pontas envenenadas são mergulhadas de frente, no fundo do carcás wepoone. Existem diversos modelos deste carcás. Dentro dele, pequenos compartimentos de fibra do pecíolo do mirití (Mauritia flexuosa), em forma de colmeia, separam as pontas das flechas e mantém o veneno isolado das condições climáticas externas com auxílio de paina de samaúma colocada entre as flechas, e do breu que envolve toda a parte de baixo deste artefato. $\mathrm{O}$ veneno é um produto delicado, que não pode ficar nem muito seco, nem muito úmido; do contrário, torna-se ineficaz. O carcás é, portanto, uma ferramenta de proteção ao usuário da zarabatana e, simultaneamente um container que evita a degradação do curare. Podemos dizer que os homens e o veneno dependem - e aqui faço menção ao conceito de "dependency" (Hodder, 2012) -, por motivos diferentes, do carcás. ${ }^{14}$ Assim como o arremesso do dardo depende da boa construção de uma zarabatana. Além disso, cada zarabatana é feita de acordo com o seu portador e, pelos dados de que dispomos, é um artefato de uso exclusivo de seus donos/produtores. ${ }^{15}$

\footnotetext{
${ }^{14}$ Pelo conceito de "dependência", Hodder (2012) destaca os relacionamentos entre "coisas" e entre estas e humanos. "Any thing is dependent on the other things used to make it, to use it, to repair it, to discard it." (: 47). A ideia tem a vantagem de colocar em relevo o fato de as "coisas" não estarem isoladas, uma vez que sua própria constituição física as coloca em relação com outras "coisas" - clima, bactérias, peças internas, externas etc. - e com os humanos que as utilizam, que fazem sua manutenção, as dispensam, etc.. Estas dependências ligam as coisas em cadeias heterogêneas e extensas que se distribuem espacial e temporalmente (: 48).

${ }^{15}$ Não é por acaso que alguns relatos mostram como os índios escondiam suas armas dos olhares desejosos dos colecionadores do início do século XX (Koch-Grünberg, 2005: 127).
} 


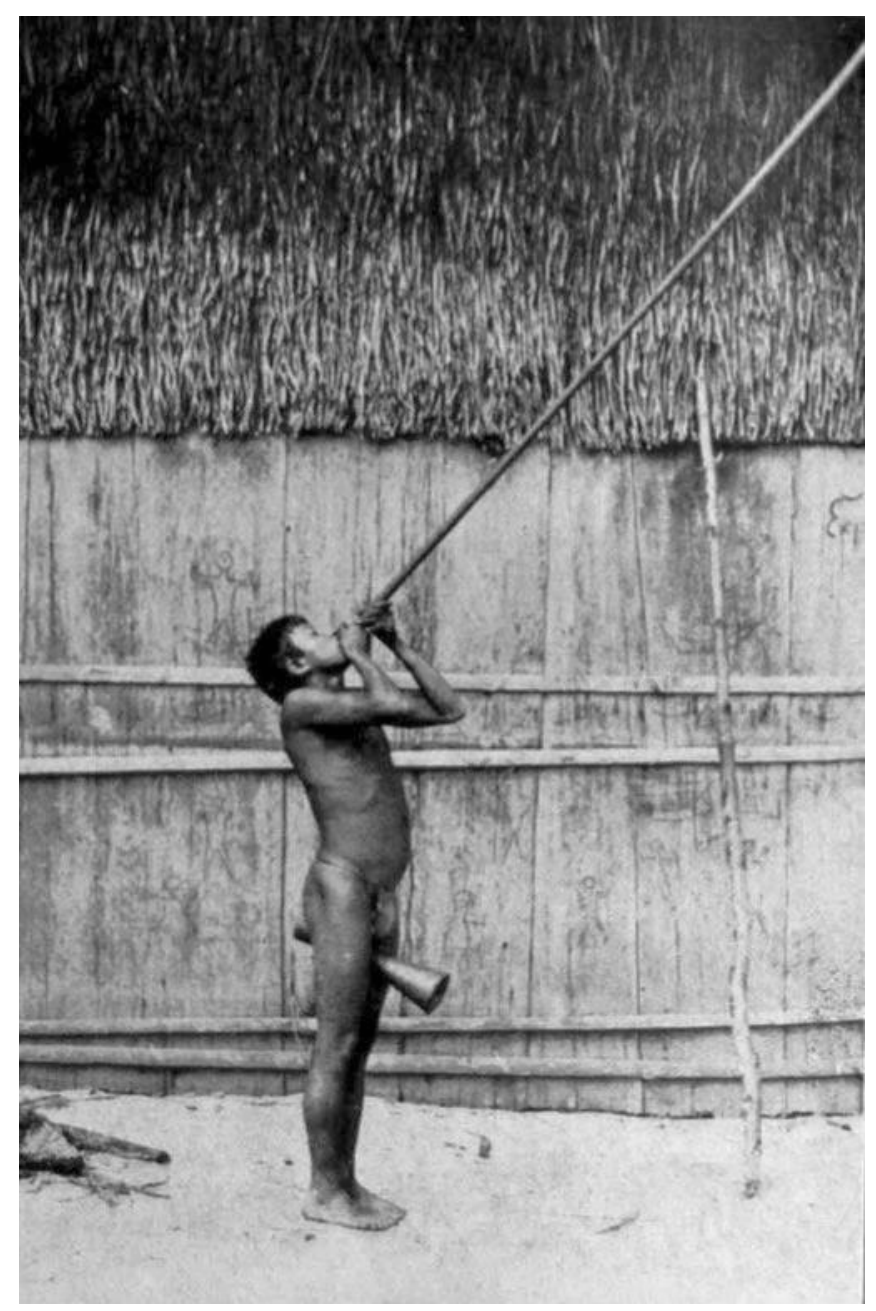

Figura 3: Índio Kauá atirando com zarabatana segurando um carcaz por entre as pernas. In: Koch-Grunberg, 2005: 127. Foto: Koch-Grünberg.

Como se vê, a cadeia de interdependência entre os componentes das zarabatanas é extremamente complexa, sendo que esta complexidade está ligada ao conhecimento de diversos ambientes, de espécies vegetais e de suas características físicas. Pode-se sugerir, por tudo isso, que por meio da sua relação com este artefatos, tais indivíduos estão remotamente conectados aos inúmeros vegetais que empregaram na sua construção (Oliveira, 2015). E todos estes materiais, uma vez empregados na construção da zarabatana, estão em interação com o ambiente em que se situam. Eles podem se ressecar ou ficar demasiado úmidos; podem também se partir, quebrar ou mesmo serem consumidos por insetos e micro-organismos. 


\section{Plantas como remédios que atuam nas relações com animais}

O/a leitor/a deve ter percebido que, ao tratar da caça e da pesca, não cesso de me deter sobre as plantas. De fato, os vegetais cumprem diversos papéis e atuam, sobretudo, como mediadores dos relacionamentos entre humanos e animais nãohumanos. Um destes papéis é o de remédio ou antídoto usados em contextos diversos. No caso de um acidente com curare, por exemplo, em que inoculassem em si mesmos ou em outro humano este veneno, os Baniwa servem-se de eettipa, eettipa hipolene, e opo hipolene contra a ação paralisante do veneno. ${ }^{16}$

Para evitar aqueles que são os maiores temores dos caçadores, os Baniwa empregam tsitsinapali, contra picada de aranhas, e hawadza, heema phelomanii e outras plantas, contra picadas de cobras. Uma vez que as caçadas se dão frequentemente à noite - horário de atividade de muitos animais peçonhentos - e no ambiente em que eles vivem, o recurso a estes antídotos é um conhecimento que favorece a caça. ${ }^{17} \mathrm{Um}$ caçador que conheci renovava constantemente o estoque destas plantas transportadas em um pequeno alforje. Se algo lhe ocorresse, dizia, era preciso mastigar a planta e colocá-la, triturada e amolecida pela saliva, sobre a picada do animal. Em nossos levantamentos em campo, percebi que estas plantas estão frequentemente presentes nas trilhas e que algumas delas parecem ter sido manejadas, no passado, de modo a crescerem nos acessos que levam os índios à floresta. ${ }^{18}$

Hipadapi, a "pedra-cipó", e piira são eficazes na cura de feridas inflamadas causada por yoopinai. Estes são seres que afligem os humanos - sobretudo em suas atividades nas florestas, causando-lhes doenças de pele e olhos, dentre outros tipos de infecções. Algumas destas plantas são úteis para o caso de os alimentos de origem animal, ingeridos pelos humanos, causarem-lhes doenças. Este é o caso de iñeewiapo, "pau de ariranha", que cura whiokali ittápe, a diarreia causada pelo "pitiú" de peixe. ${ }^{19}$

\footnotetext{
${ }^{16}$ Eettipa não é exatamente uma planta, mas um conjunto de espécies reunido pelos Baniwa sob este nome em função de servirem como alça dos aturás - kaame - que as mulheres levam à testa.

${ }^{17}$ Alguns vegetais como kamarapheapo, kamarapheapo panali e ttaittairo, agem especificamente contra picada de jararaca (o último, contra o inchaço causado pela picada).

${ }^{18}$ Outras plantas, menos do que curar doenças ou remediar acidentes, funcionam como índices, não da presença de um determinado animal, mas de todo um conjunto deles. Este é o caso de ooada, árvore que dá uma pequena fruta vermelha, que frutifica em cerca de 5 a 5 anos. Tal frutificação indica a entrada em uma época perigosa, marcada pela presença de jararacas e outras cobras peçonhentas (sobre a noção de "tempo/era" no alto rio Negro ver o trabalho de Cayón, 2010).

${ }^{19}$ Animais da floresta e os peixes tem donos (liminali) seres diversos que os Baniwa traduzem pelo nome pan-amazônico de "curupira", no primeiro caso, e "sucuriju", no outro. Algumas doenças são
} 
Há plantas, finalmente, que potencializam as atividades de caça e pesca. Apidza panattemi é utilizada para se andar rápido no mato. Ipeko panate, o "remédio do macaco da noite", é pingado sobre os olhos para espantar o sono do caçador durante suas caminhadas noturnas em busca de alimentos. Maimaipheni apura a eficácia do caçador e pescador. Ele passa a matar animais com apenas um tiro ou flechada. ${ }^{20}$

Estes exemplos permitem que coloquemos a questão: o que exatamente é a caça e a pesca? - já que tais atividades são o resultado de diversas interações entre humanos, vegetais e, claro, animais. A hipótese que pretendo perseguir neste texto é que tais atividades são resultado da produção de uma interface humano-vegetal às quais se somam componentes territoriais e animais. É esta interface híbrida que age. São homens com plantas, em determinados territórios, que caçam. Elas afastam o sono, ajudam a correr nas trilhas, são misturadas em venenos que paralisam os músculos dos animais, possuem dureza, flexibilidade e a precisão necessária aos objetivos da caça e, fundamentalmente, conduzem os caçadores até os animais. Assim, a floresta, menos do que um espaço neutro de atividades, é melhor compreendida como uma rede de índices (Ingold, 2011), um campo de possibilidades partilhadas (Gibson, 2014[1979]) e também um ambiente que circunscreve as atividades humanas, impondo-lhes limites (Oliveira, 2015).

\section{A pesca}

Diante do que foi exposto acima é curioso que se repita frequentemente que a pesca é atividade preferencial dos índios do alto rio Negro. Esta afirmação parece ser fruto de um bias Tukano que, frequentemente, permeia a literatura da região. De fato, parece que, pela relação "simbiótica" que estes grupos mantém com indígenas Maku (Ramos, 1980), eles são menos afeitos à caça, obtendo junto de seus parceiros carnes de animais e outros "produtos da floresta" (C. Hugh-Jones, 1979: 52). Este não é o caso dos Baniwa, nem dos Maku, como se pode imaginar. Independentemente disso, em toda

consideradas resultantes de um ataque destes donos aos humanos. Sobre doenças para os baniwa ver Garnelo (2003).

${ }^{20}$ O efeito é obtido por meio de uma combinação de propriedades desta planta e de uma formiga que vive em seus galhos. A aplicação do remédio consiste em agitar as folhas da planta sem largá-las, de modo a atrair as formigas que ali vivem para picar a mão e os braços da pessoa que está agitando o galho. $\mathrm{O}$ remédio é mais eficaz quanto mais distantes da mão as formigas chegarem - e picarem - aquele que segura a planta. Trata-se, portanto, de um "contexto" planta-formiga, com o qual um ser humano se envolve tendo em vista um fim terapêutico relacionado à caça e à pesca. 
região, a pesca é uma atividade especialmente difícil e para a qual inúmeras técnicas foram desenvolvidas pelos Tukano e os Baniwa - aqueles que tem acesso aos maiores cursos de rio da bacia do alto rio Negro. Repassar tais técnicas servirá para aprofundar nossa compreensão etnográfica daquilo que, aqui, estou chamando de interfaces híbridas.

\subsection{Técnicas de arco, flecha, zagaia e anzóis}

O uso de iscas é fundamental para a pesca de um modo geral, existindo diferentes modos de associar iscas e o conhecimentos dos ambientes e dos hábitos dos peixes nesta atividade. O primeiro uso que nos interessa aqui são as técnicas que empregam arco, flecha, zagaias e anzóis. ${ }^{21}$ Arcos, pontas de flechas e anzóis eram feitos de madeiras duras, antes do emprego de pequenas peças afiadas de metal. Dentre estas madeiras, os baniwa citaram kereri, kawina e kadaapo - todos vegetais de terra-firme. O corpo das flechas, as varas ou "caniços" de pesca e as zagaias, são feitos de materiais firmes e mais leves, como a paxiúba (Socratea exorrhiza) e ttidoa. As varas de pescar são feitas a partir de espécies vegetais típicas da terra firme e da caatinga. ${ }^{22}$ As pontas de zagaias eram feitas de paxiúba, e hoje são de metal.

Um ponto interessante sobre os artefatos de pesca é que as puçangas também podem ser aplicadas sobre eles. Flechas, zagaias e anzóis recebem a substância em suas pontas para que se tornem mais eficazes, assim como se faz com os humanos. ${ }^{23}$ Estes artefatos são utilizados em técnicas associadas ao uso de canoa e remo - este último leme e motor nos rios da Amazônia, cujo emprego na pesca é fundamental, por não fazer o mesmo ruído que os motores a combustão.

Sobre um pequeno casco monóxilo, os índios percorrem os igarapés em buscas dos locais ideais para a pesca. A escolha destes locais é feita seguindo os dois eixos apontados mais atrás a partir do trabalho de Frison (2004): a leitura territorial e o

\footnotetext{
${ }^{21}$ Os termos em baniwa para tais artefatos são, respectivamente, dzáawithiapoti, kaapawi, dzamapali e itsa.

${ }^{22}$ Pontas de flechas e anzóis, no passado, eram também feitas de ossos de animais. Os anzóis seriam usados, segundo os Baniwa, antes mesmo do contato com os não-índios.

${ }^{23} \mathrm{O}$ mesmo ocorre com as armadilhas (ver Corredor, 2011: 105). Na Mitoteca Baniwa (Garnelo, 2005) lê-se que havia um tipo de monotsi para zagaia: "para fazer este remédio tinha que ser do mesmo jeito que se faz para monotsi pegar mulher; tinha que fazer jejum e evitar relação sexual. Tudo isso tinha que ser feito para confeccionar uma zagaia. Depois que ela estava pronta, ele podia voltar à sua vida normal." (: 158). Esta zagaia, segundo um interlocutor, não poderia ser levada para a casa do dono. Se o fosse, causaria nas pessoas com quem ele convive o que causa nos peixes: paralisia.
} 
conhecimento etológico. No caso da pesca, tal identificação varia ora em função da frutificação das árvores localizadas nas margens, ora em função da mudança do nível do rio e do modo como tal mudança altera a circulação dos peixes. No primeiro caso, o pescador pode apenas esperar que os peixes emerjam para pegar os frutos. No segundo, ele mesmo jogará determinadas iscas ao rio, atraindo os animais. Em ambas as situações, com a subida do peixe à tona, ele atirará flechas e zagaias munidas de ponta "fisga". Tais flechas são endentadas e não saem do corpo do animal. Ajudam também que ele boie após o abate. As principais iscas para flecha e zagaia incluem, além de dzeeka inaaka, o fruto de seringa, mencionado acima, alguns insetos como o besouro deetto, e os marimbondos piitthero, ttapa e pittiñeni. Todos são arremessados vivos à água, o que faz de sua movimentação um componente fundamental na interface híbrida que pesca.

$\mathrm{O}$ recurso às técnicas que envolvem o uso de linhas e anzóis abrange um número maior de iscas, utiliza-se os frutos da seringa; de taalidzeka; de waamaatti, seringa da caatinga; de taaliawiñani, uacú do pacú; de mapoolootti, umiri (Umirium balsamiferum). Utiliza-se também alguns animais, como a minhoca da beirada, grande e pequena; a minhoca de capoeira; e a preferida e rara minhoca da serra, hipaapi; além de dzaaka, um tipo de camarão. Finalmente, um inseto, o gafanhoto tiiaali, é também empregado como isca viva. ${ }^{24}$

A maior parte das iscas é utilizada na técnica de pesca com varas ou "caniços". Nesta, o pescador simula, o tempo todo, a queda das iscas na água, com movimentos de arremesso e puxada do caniço, ao qual está presa uma linha curta de curauá ou nylon. $\mathrm{O}$ mesmo ocorre na técnica de linhada, mas sem o caniço. Já no anzol de espera são amarrados vários anzóis que ficam boiando, sendo as iscas gafanhotos colocados vivos nos anzóis (ver mais abaixo).

Arcos, flechas e zagaias podem ser usados também em uma técnica noturna de pesca em que se utilizava antigamente o kamaraita ("turi”, em língua geral, da árvore kamaraina) e hoje se emprega lanternas. Com a lanterna ou com o turi localiza-se os peixes dormindo em certos locais - como praias, durante a estiagem de verão, e abaixo

\footnotetext{
${ }^{24}$ Para se ter ideia da importância destes componentes animais, basta dizer que os Baniwa Hohodeni transplantaram estas minhocas da serra de Mothipani, uma serra situada no igarapé Dzokoali, para Iralina, local do Igarapé Uaranã próximo à aldeia onde vivem. Estes territórios distam cerca de 4 a 6 dias de viagem em canoa movida a remo. Tal transporte visou facilitar o acesso a este recurso indispensável para se pescar certos peixes típicos do início da estação chuvosa, como o peixe aadzáka, "daquiru" em língua geral (Leiarius spp.). Estas minhocas são, inclusive, objeto de transações comerciais entre os índios que tem e os que não tem acesso a estas iscas.
} 
de determinadas árvores de igapó - atirando-se contra eles as flechas e zagaias. A técnica noturna é empregada também na caça. Chama-se "fachear". Nesta caso, percorre-se os igarapés, em canoas, iluminando as margens. O facho de luz funciona como isca para os animais terrestres que acorrem aos cursos d’água para saciar a sua sede. Ao serem iluminados, ficam paralisados, olhando fixamente a luz. Dado o hábito que tem nesta técnica, os baniwa reconhecem os diversos animais que caçam somente pela diferença entre o brilho dos olhos de cada espécie iluminados no escuro.

Em todos os casos o que vemos quando divisamos o pescador, sobre a sua canoa, ou à beira do rio, usando iscas, artefatos e seu conhecimento da etologia dos peixes? Vemos um ser híbrido. Não é possível dizer que é somente o humano que pesca, mas sim esta mistura humano-artefato-isca. E, mais do que isso, há também um envolvimento/engagement com o ambiente (ver Ingold, 2011; Hodder, 2012) que é fundamental, como eu já disse. Por meio destes artefatos, os humanos irão se envolver com os diversos nichos do território que habitam. Tal envolvimento se mostra de forma mais clara ainda no caso das armadilhas e das tinguejadas, técnicas que apresentarei à seguir, na penúltima seção deste artigo.

\subsection{Técnicas de armadilhas}

Geralmente divide-se as armadilhas da região entre fixas e móveis (Cabalzar 2005: 301ss). As primeiras são os grandes cacuris e caiás. As demais são de diversos tipos, como veremos. ${ }^{25}$ Como nos interessa menos a capacidade de transporte do que a relação entre a presa e o predador implicada na armadilha, sugiro uma divisão destes objetos em dois grupos: a) armadilhas que utilizam apenas características dos cursos d’água para funcionarem e, b) armadilhas que, além destas características, utilizam iscas para atrair os peixes. Em ambos os casos, o comportamento animal está suposto no modelo da armadilha, como comentarei mais abaixo.

\footnotetext{
${ }^{25}$ No Içana e Aiari, onde vivem os Baniwa, não se encontram as grandes armadilhas de cachoeiras chamadas caiá, em língua geral (ver figura 4), que podem ser vistas nas corredeiras do Uaupés, onde vivem os povos que falam línguas da família Tukano Oriental. O caiá é uma grande esteira (“jirau”, em língua geral), feita de paxiúba e suspensa ao nível superior de uma cachoeira. É uma estrutura grande e sólida, que suporta o peso de vários homens adultos. Os peixes que sobem e descem a cachoeira são conduzidos por um cercado de varas estrategicamente posicionado. Como o jirau é longo e cercado de ambos os lados, os peixes não conseguem mais pular na água e morrem (adaptado de Cabalzar, 2005: $310)$.
} 
A produção e a colocação destas armadilhas são atividades familiares, em que trabalham juntos pais e filhos. Tais artefatos são considerados propriedades destes sujeitos, não sendo permitido a outras pessoas a coleta dos peixes neles capturados. Esta propriedade se estende, também, aos territórios em que os objetos são instalados. ${ }^{26}$ Desta forma, o emprego destes artefatos permite uma apropriação de uma porção de território equivalente à abertura de terrenos para o cultivo. ${ }^{27}$

A interação com as armadilhas é uma atividade perigosa. Não só por se tratar, algumas vezes, de artefatos colocados em trechos de forte correnteza, na proximidade de pedras; mas também por que, não raras vezes, outros animais - como cobras peçonhentas - podem ser capturados, ou se prenderem, no interior destes objetos.

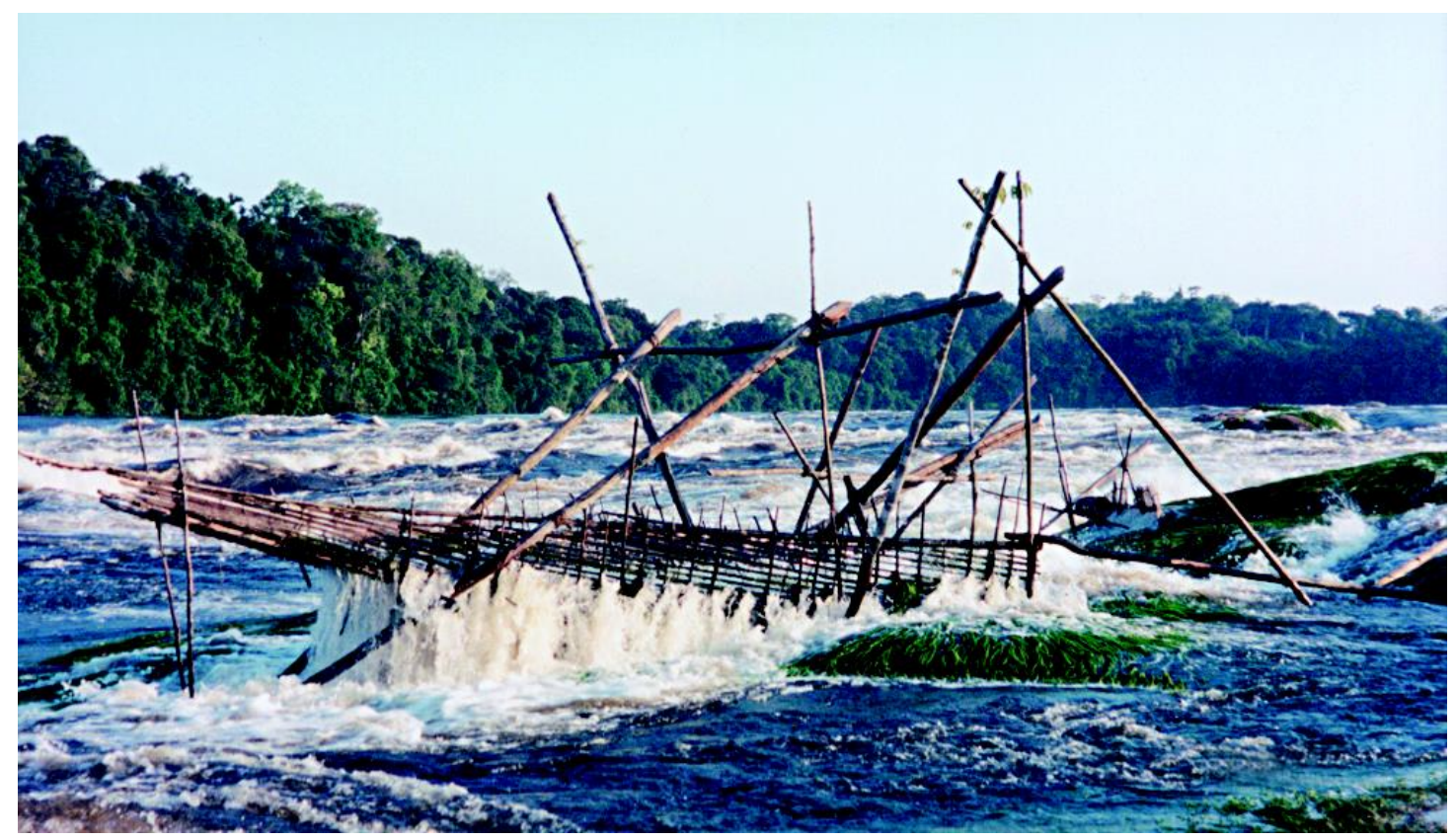

Figura 4: Caiá no rio Uaupés - In Cabalzar, 2005: 310 - Foto: Aloísio Cabalzar/ISA.

\footnotetext{
${ }^{26}$ Berta Ribeiro (1995) registrou entre os Desana tanto a propriedade das armadilhas quanto a proibição de se retirar os peixes das armadilha de outras pessoas (: 175).

${ }^{27}$ Os Baniwa afirmam uma forma "lockeana" de direito sobre a terra, na qual o trabalho se converte em propriedade. A abertura de uma roça equivale à tomada de posse de um terreno. A partir dela, a família adquire o direito de explorar o terreno indefinidamente, cabendo somente a si autorizar o uso da área por terceiros. Observa-se, ainda, o costume de pedir autorização para fazer coletas em capoeiras que não são de roças abertas pela própria família (ver Journet, 1995: 58, sobre os Koripako). Ribeiro (1995) aponta a existência de divisão hierárquica de territórios de cultivo e de áreas de pesca entre os Desana no Tiquié (: 107). Os clãs de alta hierarquia teriam para si as melhores áreas para realização de ambas as atividades.
} 
Finalmente, no que se refere ao processo de construção destes objetos, há que se ressaltar o papel dos diversos tipos de cipós nas amarrações destes artefatos - todo o conjunto depende do sucesso destas amarrações e de sua constante manutenção. Elas são feitas, no geral, por meio de uma técnica de trançado torcido e gradeado.

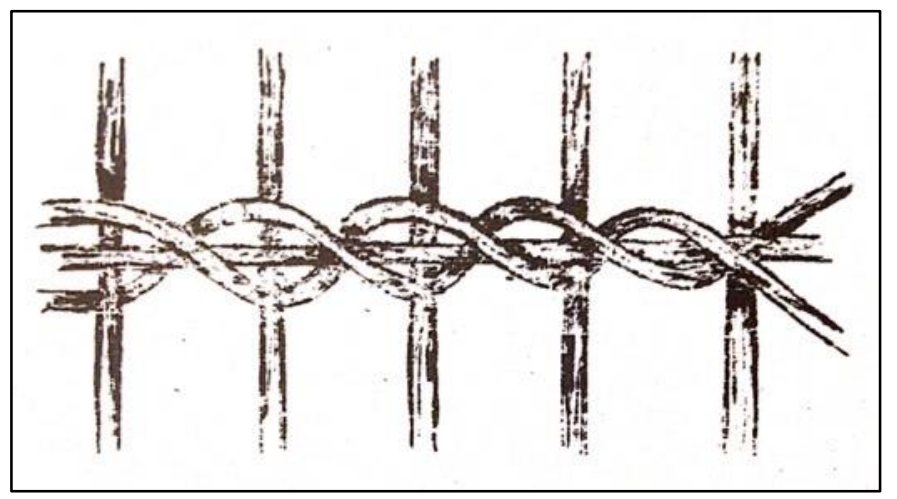

Figura 5: Trançado torcido gradeado. In: Ribeiro (1988: 69). Ilustração de Hamilton Botelho Malhano.

Emprega-se na elaboração destes objetos, basicamente, os mesmos materiais. As armadilhas de maior porte, são feitas de maawi, jupati, e daapi kanhetsa, cipó-titica; as de menor porte são feitas de peritta, talo de bacaba e hemáaphi. Com exceção do cipó-titica, estes materiais são de acesso relativamente fácil, estando disponíveis em terrenos de terra firme e de capoeiras. Não se encontram, contudo, tão facilmente nas áreas de predomínio de campinarana, próximas aos lagos e igapós do baixo Aiari e médio Içana.

\subsection{Armadilhas de isca}

Comecemos esta análise pelas armadilhas do segundo tipo, aquelas que utilizam iscas. Entre os Baniwa encontramos máawipoko (cacuri fixo) e haali (cacuri portátil). Mawipoko, é uma armadilha específica para ser utilizada nas áreas submetidas sazonalmente à inundação dos rios, os igapós. Trata-se de um cercado em forma de coração, com uma abertura de um dos lados na parte central, por onde os peixes passam e não conseguem retornar. É das armadilhas mais comuns de ser ver no Içana, sua altura sendo de cerca de 3 a 4 metros, ocupando uma área de cerca de 2 a $3 \mathrm{~m}^{2}$. 


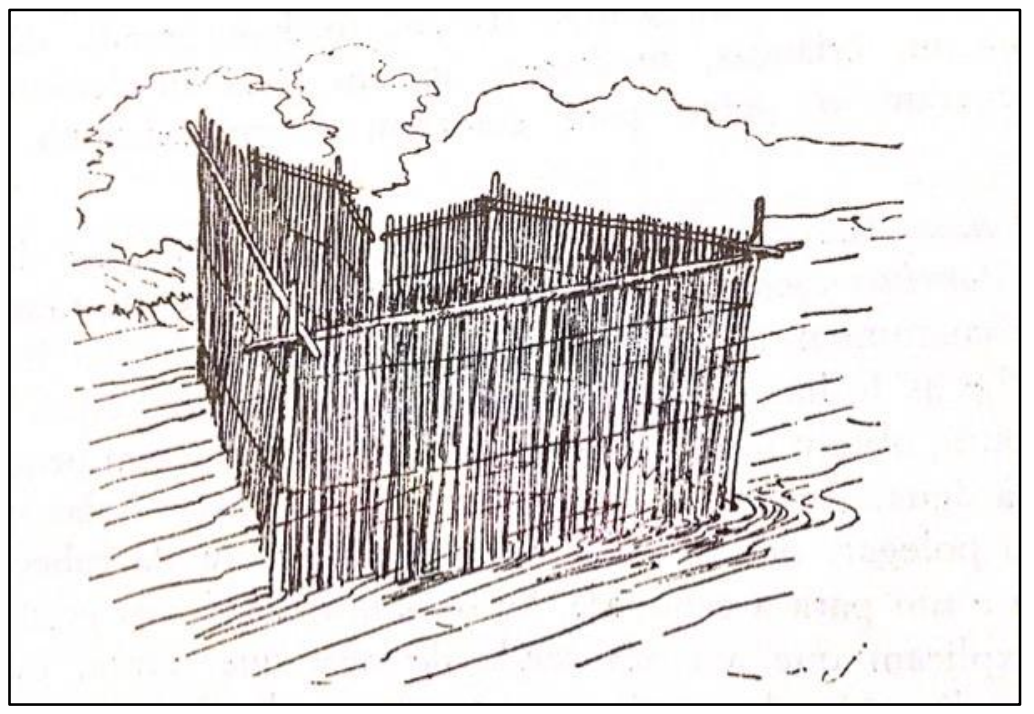

Figura 6: Cacuri fixo. In: Bruzzi da Silva 1977: 212

O fato de serem fixas é relevante na medida em que a associação entre o objeto e o local tem uma eficácia durável - o objeto não espanta os peixes, como ocorre com as malhadeiras, por exemplo. Haali, o cacuri móvel, por sua vez, é uma armadilha de pesca específica para se pegar piabas (Characidae, família) durante a piracema destas espécies. Ela tem o mesmo formato de máawipoko, sendo consideravelmente menor e feita de materiais mais leves, uma vez que visa pegar peixes de cerca de $10 \mathrm{~cm}$ de comprimento. No cacuri fixo utiliza-se somente frutos como isca: fruto do uacú; do açaí; da paxiúba; do inajá e kaini. No cacuri móvel, utiliza-se kamara, um tipo de cupim e pootida, um tipo de formiga.

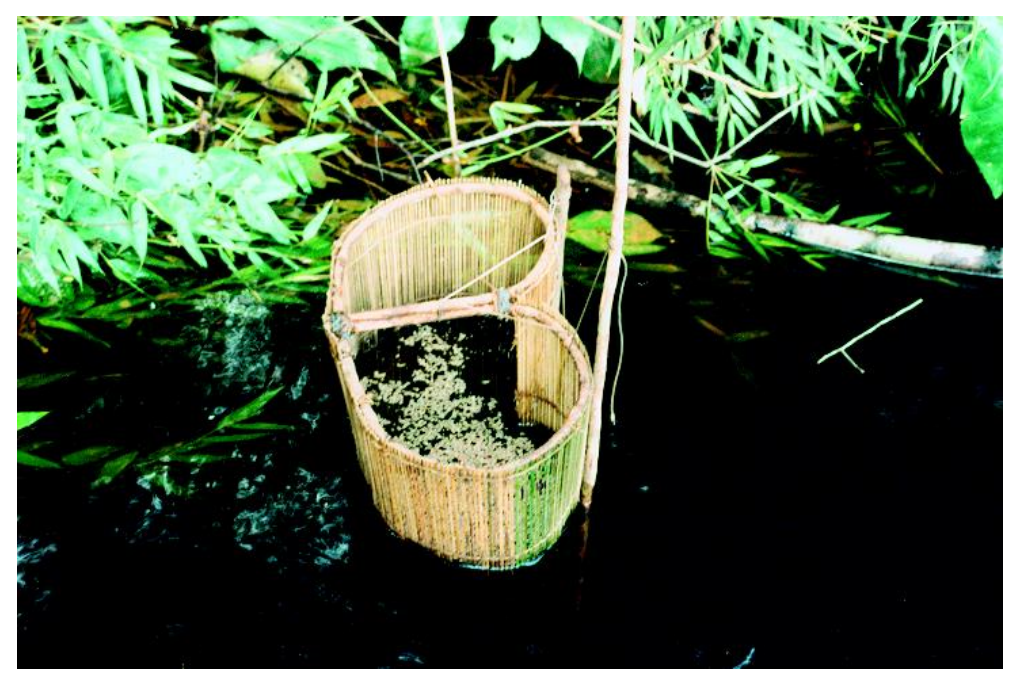

Figura 7: Cacuri Móvel. In: Cabalzar, 2005: 311 - Foto: Pieter van der Veld/ISA. 
Existem alguns tipos de armadilhas com anzóis e iscas mais modestas, que pegam menos peixes, mas que exploram igualmente as características do terreno na produção de interfaces híbridas. Cito alguns exemplos presentes entre os Desana do Tiquié. Há o kasatuti ${ }^{28}$, uma vara que sustenta um cesto cônico colocado com a abertura para cima, iscas no interior e preso por algumas estacas. "Quando o peixe entra e mexe na isca o gancho se solta e puxa o cone, com o peixe lá dentro, para cima" (Cabalzar, 2005: 312).
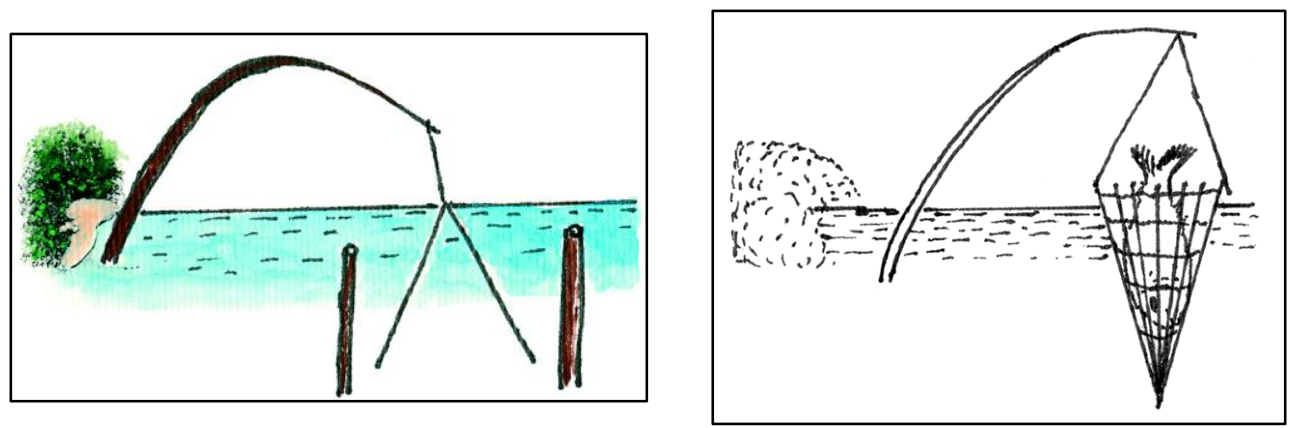

Figura 8: Kasatuti. In: Cabalzar, 2005: 312. Ilustração de Feliciano Lana/ISA.

O Anzol de espera, mencionado acima, consiste em galhos presentes na vegetação da beira do rio que são usados como varas, aos quais são amarradas linhas com anzóis e iscas. Frequentemente usa-se muitos anzóis, em uma boa área de pesca (Cabalzar, 2005: 313).
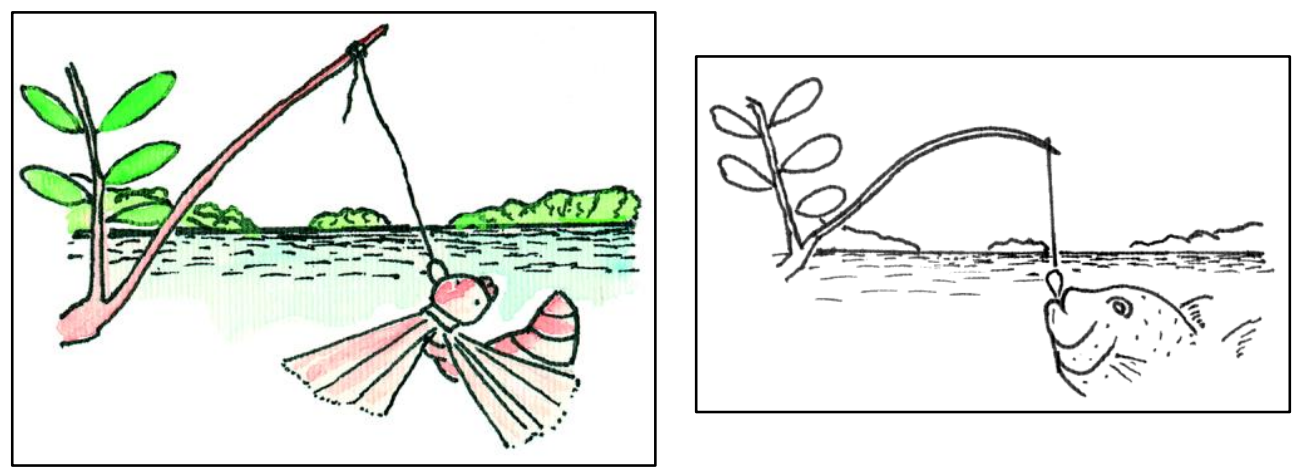

Figura 9: Anzol de espera. In: Cabalzar, 2005: 313. Ilustração de Feliciano Lana/ISA.

\footnotetext{
${ }^{28}$ Nome em língua tukano.
} 
O "pulado", é outra técnica interessante por fazer uso da vegetação da margem de determinados lagos. Trata-se também de um anzol preso a uma vara de madeira envergada a partir da beira. Contudo, aqui ele é afundado e preso a outra vara fixa no fundo do rio com auxílio de um gancho.
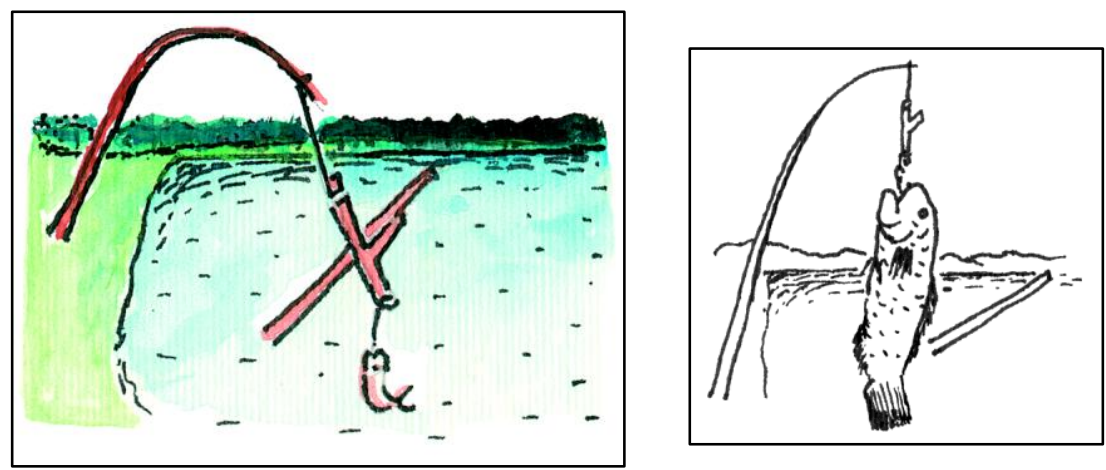

Figura 10: Pulado. In: Cabalzar, 2005: 314. Ilustração de Feliciano Lana/ISA.

"Quando o peixe puxa o anzol, a vara à qual está atado se solta do gancho, voltando a sua posição [original] e puxando o peixe para fora d água." (Cabalzar, 2005: 314). Visitando a armadilha, o pescador encontra o peixe que "virou fruta" (Gell, 2001: 187) e poderá ser "colhido" como tal.

\subsection{Armadilhas sem isca}

No caso das armadilhas que não usam iscas, é a relação de encaixe entre a armadilha e os nichos do território que constitui a interface híbrida que pesca. São quatro estas armadilhas entre os Baniwa. A maior delas, o kakoli, tem o nome derivado do termo cacuri, em língua geral. O kakoli é utilizado nas beiras dos rios e nas cachoeiras. Trata-se de uma versão ainda maior de máawipoko, associada a dois cercados colocados de cada lado para conduzir os peixes para a entrada do artefato.

Todos os cacuris prendem os peixes por um princípio simples. Seu desenho exterior conduz os peixes para dentro, enquanto seu desenho interior os impede de sair por reconduzi-los continuamente no sentido contrário da entrada (Cabalzar, 2005: 311). 
Outra destas armadilhas que retém os peixes é a dzarokana ("nassa", na terminologia museológica, ou “jequi”, em língua geral). Esta é uma armadilha formada pelo encaixe de dois cones - um como entrada dos peixes, outro como gaiola.

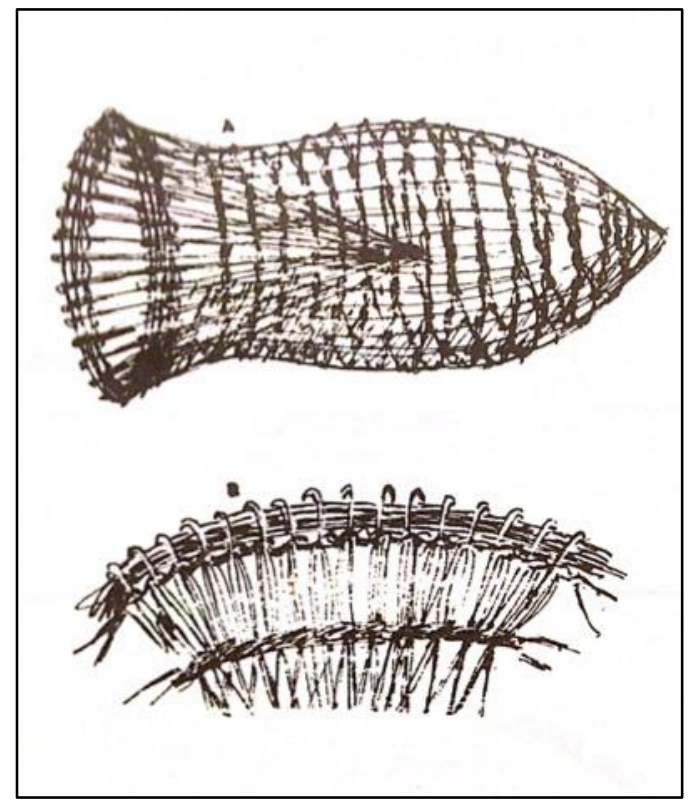

Figura 11: Nassa. In: Ribeiro, 1988: 53. Ilustração de Hamilton Botelho Malhano.

Ela é colocada em trechos do igarapé em que se encontram corredores naturais para os peixes, como pedras em corredeiras e trechos acidentados de paranás, explorando o comportamento dos peixes nas travessias cotidiana dos cursos d’água. Para instalá-la, faz-se uso de estacas e de um cercado que torna a entrada da armadilha um remanso convidativo (dado represar a correnteza) para os peixes. Assim eles entram no funil interno e não conseguem fazer o caminho no sentido contrário, ficando presos. Segundo Cabalzar (2005), "é mais usada em locais de correnteza, nos igarapés pequenos e em corredeiras (...). É muito eficaz quando o rio e os igarapés começam a encher e os peixes se juntam para fazer piracema." (: 311$)$. Neste exemplo fica mais claro como estas armadilhas criam um ambiente propício para que os animais se sintam atraídos para adentrá-las. Conjugadas ao ambientes, as armadilhas criam um nicho, categoria que, na ecologia, descreve um conjunto de características ambientais que estão associadas ao comportamento de determinado animal. $\mathrm{O}$ "nicho implica um tipo de animal, e o animal implica um tipo de nicho" (Gibson, 1979: 128 apud Hodder, 2011: 50). 
Oopitsi é uma armadilha usada para pegar peixes em migração. Conhecida pelo nome técnico de "covo", tem a forma de um funil, apresentando um estreitamento após uma entrada mais ampla. Por conta desta "cintura", a armadilha não permite que o peixe capturado se vire para sair do interior.

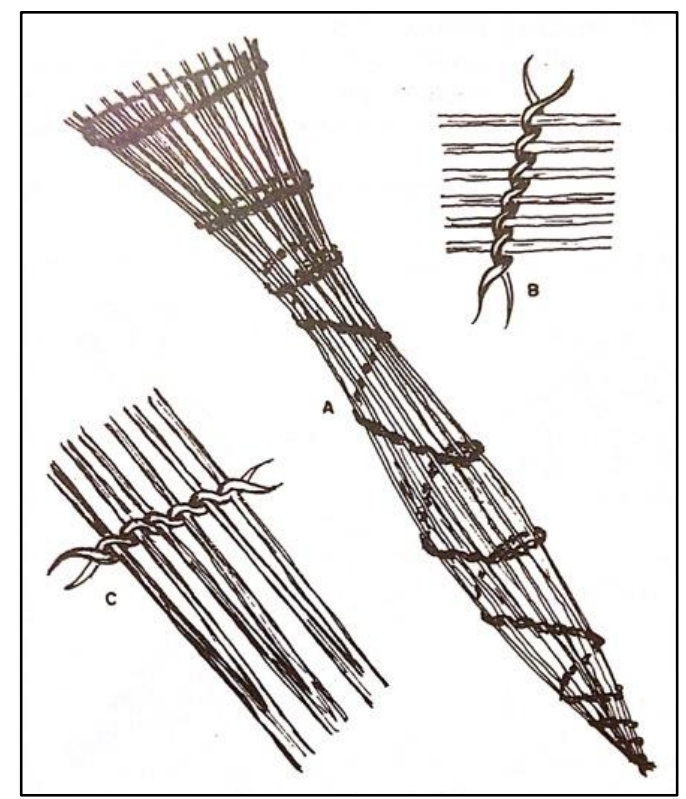

Figura 12: Covo. In: Ribeiro, 1988: 51. Ilustração de Hamilton Botelho Malhano.

Há, por fim, uma armadilha chamada $K a d z a$, em que se pega piabas durante a piracema destes peixes. Ela é como um caiá (ver nota 25) em miniatura, feita de uma grande esteira e estacas que a sustentam. 


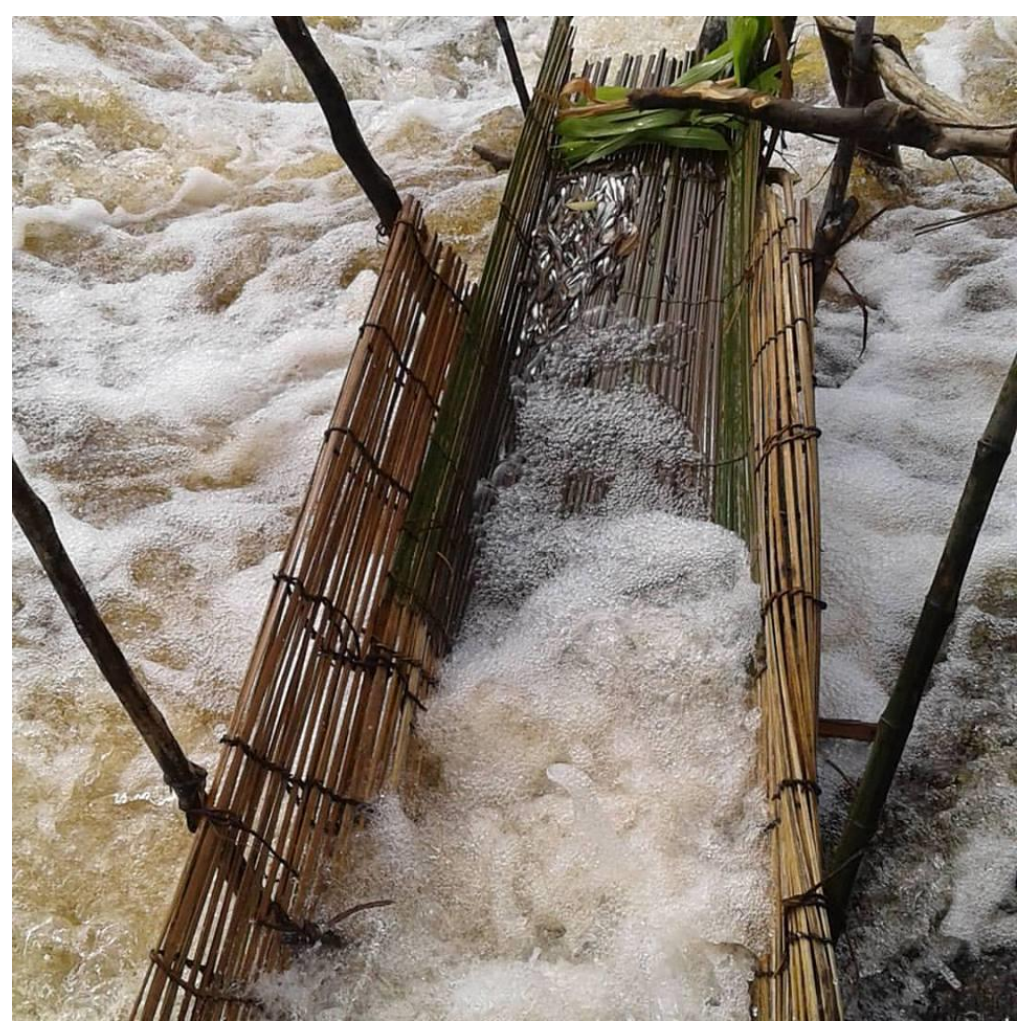

Figura 13: Kaadza - Foto: Juvêncio Cardoso/Baniwa.

Nota-se que, da mesma forma que algumas iscas, dada a sazonalidade da frutificação das árvores, só podem ser empregadas em determinados períodos do ano, há igual contingenciamento no uso das armadilhas, mas desta vez relacionado à temporalidade dos peixes. O uso de armadilhas de piracema é, na verdade, um caso particular da relação mais ampla que as atividades de pesca tem com a temporalidade dos peixes, dos animais e dos vegetais empregados nas técnicas de caça e de pesca.

\subsection{Técnicas de veneno}

O uso de Koona, timbó, se aproxima em alguma medida das técnicas de armadilha. ${ }^{29}$ Esta técnica também relaciona o comportamento das espécies de peixes ao conhecimento da geografia dos rios e igarapés. Enquanto as armadilhas acima precisam de água em movimento, o timbó é usado com água parada (Ribeiro, 1995: 174). Utiliza-

\footnotetext{
${ }^{29}$ Existem duas variedades de timbó entre os Baniwa. Koona é encontrada dispersa na natureza. Alikoonani é cultivada e considerada superior. A primeira espécie tem origem mitológica na urina de um velho que foi levado por um gavião para um passeio no céu. Nos pontos em que caiu a urina, cresceu a planta que os índios coletam hoje.
} 
se o timbó em lagos naturais, no período da vazante, ou represa-se pequenos igarapés com cercados feitos de jupati chamados "pari”, em língua geral, quando da piracema de alguns peixes. Segundo Brüzzi da Silva (1977), em alguns casos os índios, tendo escolhido o local da tinguejada, "cevam-no", ou seja, jogam alimentos para que os peixes passem a se concentrar em maior quantidade ali (: 211). Uma vez atraídos, são retidos e asfixiados com o timbó.

\section{Interfaces híbridas}

Meu principal argumento até aqui foi que o conhecimento do comportamento animal e do território habitado pelos índios do alto rio Negro está materializado e codificado em artefatos e técnicas de caça e pesca empregados nesta região. Na última parte deste texto, gostaria de tecer alguns comentários que procuram refinar tais observações. O farei a partir de um diálogo com um trabalho de Alfred Gell (2001[1996]) que se deteve sobre o tema da relação entre armadilhas, obras de arte e a eficácia de ambas - um texto que ficou famoso pelo debate com Arthur Danto e Susan Vogel sobre as relações entre arte e artefato.

Comentando uma armadilha de caça feita de setas apontadas para um animal que, passando desavisado, ativa o seu mecanismo e morre flechado, Gell afirmou que neste artefato seria possível "ler a intenção do seu autor e o destino de sua vítima" (: 183). Para Gell, armadilhas, de um modo geral, são um "modelo de seu criador". Elas são "uma espécie de caçador substituto, (...) [que caça] para seu dono." Ao mesmo tempo, elas são, também, "um modelo da vítima" e o são de tal modo que constituem "um texto sobre o comportamento animal" (: 184) inscrito na forma de artefato. Contudo, segundo o autor, mesmo que as armadilhas ajam por si próprias e sejam uma coisa que equivale a uma pessoa, estas duas características não fariam deste objeto exatamente uma pessoa, pois é

\footnotetext{
"claro que a armadilha não é, em si mesma, inteligente ou enganosa. O caçador é que conhece as respostas habituais da vítima e é capaz de subvertê-las. Mas, uma vez montada a armadilha, a habilidade e o conhecimento do caçador estão efetivamente inscritos nela, de forma objetificada; caso contrário a armadilha não funcionaria." (: 183)
} 
Tais afirmações se aplicam aos casos discutidos neste artigo, e colocam em jogo dois conjuntos de relações que acompanhamos até aqui - aquelas entre humanos e animais, e aquelas entre humanos e artefatos. Considerando o material exposto neste trabalho, me parece ser possível complexificar o modelo proposto por Gell para compreender o funcionamento das armadilhas - e, eu acrescentaria, das técnicas de caça e pesca em geral - observando, justamente, estes dois conjuntos de relações. Comecemos, então, pelo último, as relações entre pessoas e coisas.

A ideia de que uma armadilha não "é, em si mesma, inteligente ou enganosa" remete à distinção entre agentes de primeira e de segunda classe presente em outro texto de Gell (1998). Nele, o autor afirma que coisas são como pessoas, tem agência no mundo, mas que tal agência não é autônoma, uma vez que, por trás dela, se revela uma intencionalidade humana. Daí a ideia de agentes de segunda classe (: 17).

Vimos, ao longo do presente artigo, alguns dados que perturbam a distinção entre estes dois níveis de agência. Para certos povos da região, como os Desana, um cacuri é um artefato, mas também uma pessoa (Corredor, 2011: 108). Ao mesmo tempo, há práticas na região, que aproximam corpos humanos de corpos não-humanos, como os benzimentos, feitos tanto sobre armas e armadilhas quanto sobre seres humanos. Menos do que contrapor o modelo de Gell a tais afirmações nativas, meu objetivo aqui é comentar, em que condições estas afirmações podem ser feitas, e como este conjunto de asserções complexifica o nosso entendimento sobre o que é a agência dos objetos para os índios do alto rio Negro.

O caso Desana é ilustrativo. Para estes índios, os cacuris são uma pessoa, mas também uma vagina e eventualmente uma flauta cerimonial (Corredor, 2011: 105, 108). Tal analogia entre pessoas, partes de pessoas (a vagina) e coisas que são como pessoas (a flauta que é um tubo) aponta para dois temas que nos interessam. De um lado, para algo que é fundamental a este conjunto de ideias: a comunicação interespecífica realizada por estes artefatos. Se os cacuris são pessoas, se tem um corpo, eles o são e os tem para os peixes. "El cacurí, además de vagina, tiene piernas, cabello, costillas, y columna vertebral. La trampa no es un tropo para aludir a una mujer: la trampa es una persona, así es percibida por los peces que acuden a ella justamente en virtud de estas características." (Corredor, 2011: 108). Tal objeto é construído para que os humanos possam se comunicar, atrair e seduzir uma outra espécie, ou melhor, um outro tipo de gente: os peixes (Corredor, 2011: 105). A ação humana por trás do cacuri é, portanto, sua construção e manutenção como uma pessoa - para isso são necessárias matérias- 
primas e atos rituais. A ação do cacuri, por sua vez, é provocar uma ação nos peixes, atraí-los. Neste sentido, eles agem a partir de uma intencionalidade humana que se dá em diálogo com a forma humanizada pela qual os índios compreendem os peixes. ${ }^{30}$ Restritos ao objeto, o produtor e a vítima, estamos no âmbito do modelo estabelecido por Gell para compreender a ação das coisas.

De outro lado, a recursividade entre conteúdo e continente presente na afirmação dos Desana chama atenção para um outro aspecto da relação entre as pessoas e as coisas: aquilo que Pierre Lemonnier (2011) chamou de "ressonância perissologica", um tipo de "conhecimento não-verbal" constituído pela redundância entre conteúdos diversos do mundo vivido de um determinado povo; conteúdo este condensado em determinados objetos. O ato de "cercar" /“conter" algo, fundamental para o funcionamento das armadilhas e técnicas de caça e pesca, ressoa também em outros campos da vida dos habitantes desta região (ver Hugh-Jones, 2014 sobre este tema). O cercado é uma noção xamânica fundamental, por exemplo, para a proteção das pessoas contra agências não-humanas. Os xamãs, em seus benzimentos, "cercam" imaterialmente as pessoas, muitas vezes evocando artefatos de pesca (ReichelDolmatoff, 1968: 81; Århem et al., 2004: 485). A maloca - uma casa feita um cercado é uma construção que inspira todo um modelo do universo (Hugh-Jones, 1995). A caixa de adornos cerimoniais - símbolo do poder de uma determinada maloca em conter potências animais e lançar mão delas em um contexto cerimonial - é também um cercado feito de fibra vegetal. As reclusões pubertárias de adolescentes se dão em cercados feitos dos mesmos materiais empregados nas armadilhas (ver Corredor, 2011: 71) - e assim por diante. Todos estes conteúdos ressoam ideológica e materialmente de modo não-verbal - nas armadilhas e no seu potencial em conter os peixes e deter o

\footnotetext{
${ }^{30}$ Não podemos perder de vista que as relações entre humanos e animais é marcada, nesta região, pela ideia de que há um fundo comum de "humanidade", ou proto-humanidade que os reúne (ver, dentre outros, Århem, 1993: 13; Corredor, 2011: 51). O que quer dizer, por exemplo, que os peixes que sobem o rio fazendo piracema são entendidos como pessoas que vão até casas cerimoniais realizar rituais de dabucuri junto a seus cunhados. Um narrador baniwa conta que os "peixes são iguais a nós. Têm épocas de suas festas, que os brancos chamam de piracema. Eles se organizam e marcam o dia para viajarem da foz dos rios até o local da festa, que é o local da piracema. Eles passam em todos os lugares onde tem parentes convidando-os para uma grande festa que ocorrerá naquele lugar. Eles levam instrumentos como japurutu e kolirina [flauta surubim]. Quando chegam no local, se alinham para dançar. Para nós eles parecem peixes, mas são pessoas, como a gente." (ver Garnelo, 2003: 94-96), Os locais em que dançam são os lagos e os outros nichos territoriais junto aos quais os humanos armam suas armadilhas, ou usam suas armas. Assim, na relação entre as espécies opera, ao mesmo tempo, uma indeterminação e uma afirmação da distinção entre natureza e cultura. Neste jogo, a diferença e a permeabilidade dos seres humanos, animais, vegetais e artefatuais é tópico fundamental para a compreensão da produção da vida neste região (ver Oliveira, 2015).
} 
seu fluxo. Da mesma forma, a ideia de armadilha ressoa nestes outros contextos. ${ }^{31}$ Assim, ao afirmarem as relações entre pessoas e coisas aqui expostas, os índios do alto rio Negro estão operando no interior de uma lógica que, por meio da oposição entre conteúdo e continente, compreende estes artefatos como tendo uma corporalidade análoga à dos seres humanos.

Mas isto não é tudo no que diz respeito ao conhecimento não-verbal e à agência dos artefatos. Um dos mitos mais difundidos na região como um todo conta como diversos nichos territoriais, como cachoeiras e corredeiras, foram criados nos tempos de constituição do mundo. Nestas histórias aprendemos que animais gigantescos como anacondas tiveram seu corpo transformado em pedras que passaram a modificar o curso dos rios, após serem mortos pelos ancestrais da humanidade atual. Dos restos de seus corpos se originaram as cachoeiras e corredeiras atuais. Uma queda nestes trechos de rio é, geralmente, fatal para um homem; assim como a entrada em uma armadilha é fatal para os peixes. A partir destas histórias é possível compreender que os humanos aprenderam a fazer armadilhas observando não só os peixes, mas também as corredeiras e cachoeiras - daí um outro sentido para a agência destes objetos e para a dimensão "não-verbal" do conhecimento envolvido no aprendizado/desenvolvimento destas técnicas. Tal desenvolvimento, sugiro, está codificado na mitologia e nas tecnologias da região.

Aprende-se sobre o animal observando o seu comportamento, mas também o território em que se vive e se relaciona com este animal. Seria preciso compreender, portanto, o animal e o nicho que ele habita como um agregado, um feixe de relações. Isso nos leva ao segundo conjunto de comentários ao modelo de Gell que mencionei acima, a relação entre humanos e animais.

A formulação de que, nas armadilhas, a relação entre humanos e animais passa pela objetificação do conhecimento dos primeiros a respeito do comportamento dos segundos (Gell, 2001: 183-4), embora precisa, subsumi na ideia de "comportamento animal" algo que é mais complexo: a contribuição das possibilidades/affordances territoriais aos projetos humanos.

\footnotetext{
${ }^{31} \mathrm{Na}$ América indígena, os "donos" de animais (ver Fausto, 2008) frequentemente são descritos como possuindo cercados onde criam seus xerimbabos. Além disso, a palavra "tocaia", do tupi-guarani, guarda diversos conteúdos, como a ideia de armadilha, cercado de iniciação, local de espreita, puleiro, etc. (Carlos Fausto comunicação pessoal).
} 
Vimos neste texto que o território é, simultaneamente, uma rede de índices e de possibilidades partilhadas entre humanos e não-humanos; e um ambiente que circunscreve as ações de ambos, ao mesmo tempo em que os põe em interação. Artefatos e técnicas de caça e pesca são, neste sentido, uma forma dos humanos atuarem em concerto com estas redes e circunscrições territorialmente específicas. Este não é somente o caso do alto rio Negro, mas um traço geral do funcionamento destas técnicas e artefatos. Nas planícies norte americanas, por exemplo (Frison, 2004), - onde humanos enfrentavam grandes animais como bisões - estratégias de caça envolviam fazer de acidentes naturais do território partes de armadilhas. Certas formações de terreno eram complementadas pelos caçadores com cercas que conduziam os animais até os chamados bison jumps, pontos a partir dos quais eles eram pressionados, saltando para a morte (81); outras formações os conduziam até currais naturais onde eram cercados para o abate (: 88). A técnica de caça de antílopes (pronghorn) envolvia semelhante interferência e aproveitamento da paisagem (: 128). E a caça de bodes e cabras da montanha era realizada somente em terrenos específicos, que permitiam uma cuidadosa aproximação e, ao mesmo tempo, a condução dos animais visados em direção às armadilhas (: 152). Em todos estes casos, seja diante da força descomunal dos bisões, da velocidade incomparável dos antílopes, ou mesmo da visão aguçada das cabras e dos bodes, as técnicas de caça são indissociáveis de sua inscrição territorial.

Se no noroeste da América do Norte o território conduzia/permitia o emprego de determinadas técnicas, o mesmo ocorre no alto rio Negro, onde diversos tipos de nichos naturais são artefatualizados pelos humanos na consecução de suas atividades. Caiás, cacuris, covos e nassas são objetos com um design específico para determinados locais. Ou numa formulação mais precisa, são objetos que interagem com as possibilidades/affordances territoriais que permitem a captura de peixes, presentes em determinados locais. Estas armadilhas e armas são "coisas" /“thing", no sentido definido pelo arqueólogo Ian Hodder (2012): são o centro de convergência de uma série de conhecimentos e concepções - o que faz com que seus designs e projetos resumam uma longa cadeia de interações entre humanos e não-humanos. ${ }^{32}$ Tal cadeia técnicas não está necessariamente visível - para todos os observadores -, quando se divisa estes artefatos;

\footnotetext{
${ }^{32}$ Para este autor fenômenos naturais, instituições, corpos, sons, animais, etc. são "coisas". Estas coisas são "pacotes de duração" mais ou menos ampla no contínuo fluxo da matéria, da energia e da informação. Por terem duração e presença, nós a consideramos como objetos discretos. Chamá-las de coisas, retomando inclusive a epistemologia anglo-saxã e alemã do termo thing/ting (ver Hodder, 2012: 48) permitiria ressaltar que tais entidades estão em fluxo e são o resultado da convergência de outras coisas.
} 
o que não quer dizer que estas relações não estejam presentes e não orientem a elaboração dos mesmos. ${ }^{33}$

Vista por esta ótica, a ação de caçadores e pescadores consiste na criação de redes sociotécnicas (Latour, 2005). A forma da objetificação aqui é, justamente, a composição de um arranjo de humanos e não-humanos nestas redes. As técnicas que vimos neste texto envolvem a articulação de uma série de atores na produção temporária e local - de um mecanismo complexo, uma espécie de máquina de caçar e pescar. Feitas de encaixes entre peças articuladas exclusivamente para aquele projeto lembremos das zarabatanas -; contando com mecanismos de redundância que garantem a sua eficácia e que operam convertendo diferentes formas de energia - a correnteza do rio, o retesamento de um arco, etc. - em produtos, a caça e a pesca. Estas máquinas híbridas fazem, inclusive, de um animal - como um besouro ou gafanhoto, por exemplo -, um ser artefatualizado, convertido em um pequeno autômato, quando inserido em seu contexto.

Menos do que um substituto, portanto, - um modelo do caçador -, as armadilhas, as armas e as técnicas aqui consideradas envolvem o corpo dos caçadores e pescadores em objetos, animais, vegetais e nichos territoriais. Esta mistura potencializa a ação destes corpos. Um cachorro fareja pelo seu dono; uma flecha disparada alcança uma vítima distante; um veneno paralisa a musculatura do animal atingido; uma armadilha "mergulha" por tempo indeterminado no rio e recolhe uma quantidade de peixes que um só homem - ou um homem só, fora de uma rede complexas de atores não teria condições de recolher.

A imagem desta potencialização e desta mistura pode ser bem captada a partir de um último exemplo - a descrição do uso de anzóis de espera entre os Desana, feita por Cabalzar (2005). Segundo o autor, no uso desta técnica, o

\footnotetext{
"pescador vai colocando até cinquenta anzóis de espera. Depois fica esperando e circulando, olhando numa e noutra isca [verificando se foram comidas por peixes pequenos e as substituindo, ao mesmo tempo que recolhem os peixes capturados]. Quando volta para casa com os peixes, retira também todas as armadilhas.’(: 313).
}

\footnotetext{
${ }^{33}$ Ver Hodder (2012: 12), sobre o aspecto front-back das “coisas". Ou seja, sobre aquilo que vemos e o que não vemos quando nos acostumamos a um determinado objeto.
} 
Esta imagem do pescador em sua canoa, monitorando e pescando em uma grande área, apresenta um corpo territorializado, feito de dezenas de braços que se distribuem às margens do curso d’água, resultado de um processo de artefatualização das plantas deste terreno. Tal imagem poderia ser confundida com a de um grande cérebro que monitora um corpo híbrido. Mas ao destacarmos excessivamente a intenção humana, estaríamos desconsiderando todas as intencionalidades aqui presentes. As iscas vivas, a correnteza leve que transporta o seu cheiro. Os galhos, igualmente vivos, em que se amarra os anzóis e assim por diante. Devemos nos atentar, portanto, ao fato de que, embora os humanos armem as redes aqui descritas para a realização de seus objetivos, eles o fazem em interação com redes já constituídas. Pode ocorrer, portanto, de a soma das agências articuladas em um projeto ultrapassar a intenção que o gerou. Cobras podem entrar inadvertidamente no cacuri posicionado em determinado local, uma ariranha pode visitar uma armadilha repleta de peixes ou o rio pode encher mais do que o previsto e inviabilizar o uso de determinada técnica. O reconhecimento da existência destas redes de atores - previstas e não previstas pelos construtores de armadilhas - permite questionar a centralidade da intenção humana nestes projetos. Tal reconhecimento seria uma forma de escapar à distinção entre agência primária e secundária de Gell (1998), situando a ação de pessoas e de coisas em um contexto mais amplo. Considerando esta pluralidade de atores, notamos então, que ao falarmos de técnicas de caça e de pesca e das redes sociotécnicas armadas neste campo da vida, estamos diante de "coisas" que estão no mundo (Ingold, 2011; Hodder, 2012), conectadas ao ambiente em que se inserem, por meio de cada um de seus componentes materiais e imateriais.

\section{Referências}

ÅRHEM, Kaj. 1993 "Ecosfia makuna", em François Correa (ed.), La selva humanizada, pp. 109-126. Bogotá: ICAN-Fondo FEN-CEREC.

ÅRHEM, Kaj; CAYÓN, Luis; ANGULO, Gladys e GARCÍA, Maximiliano. 2004. Etnografía makuna: Tradiciones, relatos y saberes de la Gente de Agua. Acta Universitatis Gothenburgensis. No. 17. Bogotá: Universidad de Gotemburgo e Instituto Colombiano de Antropología e Historia (ICANH).

BRÜZZI ALVES DA SILVA, Alcionílio. 1994 [1977]. Crenças E Lendas Do Uaupés. Ediciones Abya-Yala.

BUCHILLET, Dominique. 1988. "Interpretação da doença e simbolismo ecológico entre os indios Desana." BMPG 4 (1): 27-42.

1997. "Nobody Is There to Hear." Portals of Power: Shamanism in South America, Eds. EJM Langdonand G. Baer. University of New Mexico Press, Albuquerque. 
CABALZAR, Aloisio. 2000. "Descendência E Aliança No Espaço Tuyuka. A Noção de Nexo Regional No Noroeste Amazônico." Revista de Antropologia 43 (1): 61-88.

. 2005. Peixe E Gente No Alto Rio Tiquié: Conhecimentos Tukano E Tuyuka: Ictiologia, Etnologia. São Paulo - São Gabriel da Cachoeira: ISA/FOIRN.

CABALZAR, Aloísio, and Carlos Alberto Ricardo. 2006. Povos Indígenas Do Rio Negro: Uma Introdução à Sociambiental Do Noroeste Da Amazônia Brasileira. São Paulo: Instituto socioambiental.

CAYÓn, Luís. 2010. “Penso, Logo Crio. A Teoria Makuna Do Mundo.” Ph. D. Programa de Pós-graduação em Antropologia Social. Universidade de Brasília, 2010.

C. HUGH-JONES, Christine. 1979. From the Milk River: Spatial and Temporal Processes in Northwest Amazonia. Cambridge Studies in Social Anthropology 26. Cambridge: Cambridge University Press.

CORREDOR, Kenny Javier Calderón. "El Cacuri (Wahiro): Tecnología y significado entre los cotiria del bajo río Vaupés, Colombia." Bogotá: Universidad De Los Andes, 2011.

FAUSTO, Carlos. 2008. "Donos Demais: Maestria e Domínio Na Amazônia." Mana 14 (2): 329-66.

FRISON, George. 2004. Survival by Hunting: Prehistoric Human Predators and Animal Prey. Univ of California Press.

GALVÃO, Eduardo Enéas. 1959. “Aculturacao Indigena Do Rio Negro.” BMPEG, Nova Série, 7: 126-34.

GARNELO, Luiza. "Poder, Hierarquia E Reciprocidade Sa'ude E Harmonia Entre Os Baniwa Do Alto Rio Negro." 2003.

—. , ed. 2005. Mitoteca Baniwa. São Gabriel da Cachoeira: FOIRN - Federação das Organizações Indígenas do Rio Negro.

GELL, Alfred.. Art and Agency: An Anthropological Theory. Clarendon Press. 1998

"A Rede de Vogel, Armadilhas Como Obras de Arte E Obras de Arte Como Armadilhas." Revista Do Programa de Pós-Graduação Em Artes Visuais EBA 8 (8). 2001 [1996].

GIBSON, James J. The Ecological Approach to Visual Perception: Classic Edition. Psychology Press. 2014 [1979].

HODDER, Ian. Entangled: An Archaeology of the Relationships between Humans and Things. Malden, MA: Wiley-Blackwell. 2012.

HUGH-JONES, Stephen. "Inside-out and Back-to-Front: Tha Androgynous House in Northwest Amazonia." In: About the House: Lévi-Strauss and beyond. Cambridge: Cambridge University Press. 1995.

"Bonnes Raisons Ou Mauvaise Conscience?. De L'ambivalence de Certains Amazoniens Envers La Consommation de Viande.” Terrain, no. 26. 1996.

."Nomes Secretos E Riqueza Visível: Nominação No Noroeste Amazônico." Mana 8 (2): 45-68. 2002.

."Caixa de Pandora: Estilo Alto-Rio-Negrino."Revista de @ntropologia Da UFSCar 6: 155-73. 2014.

INGOLD, Tim. Being Alive: Essays on Movement, Knowledge and Description. London; New York: Routledge. 2011.

JOURNET, Nicolas. La Paix Des Jardins. Vol. 31. Institut D'Ethnologie Musee de L'Homme. 1995.

KOCH-GRÜNBERG, Theodor. Dois Anos Entre Os Indígenas: Viagens No Noroeste Do Brasil,(1903/1905). Edua. 2005.

LATOUR, Bruno. Reassembling the Social: an Introduction to Actor-Network-Theory. Oxford: Oxford University Press. 2005.

LOLLI, Pedro. "As Redes de Trocas Rituais Dos Yuhupdeh No Igarapé Castanha, Através Dos Benzimentos E Das Flautas Jurupari.” Tese de Doutorado em Antropologia Social. São Paulo: USP, 2010.

OLIVEIRA, Thiago Lopes da Costa. "Os Baniwa, Os Artefatos E a Cultura Material No Alto Rio Negro.” Rio de Janeiro: Universidade Federal do Rio de Janeiro. 2015. 
POLITIS, Gustavo. Nukak: Ethnoarchaeology of an Amazonian People. Walnut Creek, California: Left Coast. 2007.

RAMOS, Alcida Rita. 1980. Hierarquia e Simbiose: relações intertribais no Brasil. São Paulo: Hucitec ; Brasília : INL.

REED, Edward S. 1988. "The Affordances of the Animate Environment: Social Science from the Ecological Point of View." What Is an Animal, 110-26.

REICHEL-DOLMATOFF, Gerard. 1968 Desana: simbolismo de los Indios Tukano del Vaupés. Bogotá: Universidad de los Andes.

RIBEIRO, Berta Gleise. 1980. "A Civilização Da Palha: A Arte Do Trançado Dos índios Do Brasil." São Paulo, SP: Universidade de São Paulo.

—. 1988. Dicionário Do Artesanato Indígena. Vol. 4. Belo Horizonte / São Paulo, SP: Itatiaia / EDUSP.

Paulo: Edusp.

1995. Os índios Das águas Pretas: Modo de Produção E Equipamento Produtivo. São

VAN DER VEEN, Marijke. 2014. "The Materiality of Plants: Plant-people Entanglements." World Archaeology 46 (5): 799-812.

Recebido em: 27/10/2016.

Aprovado em: 01/12/2016. 